

\section{Prospects for Humic Acid Products from Digestate in the Netherlands}

\section{Quickscan}

Authors:

Luuk Gollenbeek ${ }^{1}$ and Rommie van der Weide ${ }^{2}$

${ }^{1}$ Wageningen Livestock Research

${ }^{2}$ Wageningen Plant Research

This study was carried out by the Wageningen Research Foundation (WR), Business Unit Field Crops and was commissioned and financed by the PPP Biobased valorisation of manure and digestate AF-17052b. This project is financially supported by the Dutch Topsector Agri \& Food. Within the Topsector, private industry, knowledge institutes and the government are working together on innovations for safe and healthy food for 9 billion people in a resilient world. WR is part of Wageningen University \& Research, the collaboration of Wageningen University and Wageningen Research Foundation.

Wageningen, December 2020

Report WPR-867 
Gollenbeek L.R., R. Van der Weide, 2020, Prospects for Humic acid products from digestate in the Netherlands, Wageningen Research, Report

This report can be downloaded for free at https://doi.org/10.18174/541280

The goal of this research was to examine the prospects for humic acid products and in particular a humic acid product produced from animal manure/digestate. Based on a literature review it is concluded that humic acids are used worldwide as biostimulants and overall positive effects on crop growth are reported, but variation in results is high. Stakeholders explained during interviews that in the Netherlands the use of Humic acid products are mostly related to niche markets. For conventional agriculture in the Netherland the value of humic acids has not been proven yet, this can be explained by the high fertility of the Dutch soils, and high yields that are already obtained without adding humic acids. Also field experiments were done. In several field experiments with potatoes and onions the specific humic acid product was tested. Adding the humic acids (on soil and as foliar spraying) did not benefit crop growth, but also did not harm the crops. No effect was found on the development of diseases.

Keywords: Humic acids, animal manure, digestate, biostimulant

(C) 2020 Wageningen, Stichting Wageningen Research, Wageningen Plant Research, Business Unit Open Teelten, P.O. Box 430, 8200 AA Lelystad, The Netherlands; T +31 (0)3200 2911 11; www.wur.eu/plant-research

Chamber of Commerce no. 09098104 at Arnhem

VAT NL no. 8065.11.618.B01

Stichting Wageningen Research. All rights reserved. No part of this publication may be reproduced, stored in an automated database, or transmitted, in any form or by any means, whether electronically, mechanically, through photocopying, recording or otherwise, without the prior written consent of the Stichting Wageningen Research.

Stichting Wageningen Research is not liable for any adverse consequences resulting from the use of data from this publication.

Photo cover: Luuk Gollenbeek 


\section{Contents}

$\begin{array}{ll}\text { Preface } & 5\end{array}$

$\begin{array}{ll}\text { Summary } & 7\end{array}$

$\begin{array}{llr}1 & \text { Introduction } & 10\end{array}$

$\begin{array}{llr}2 & \text { Information on humic substances } & 11\end{array}$

2.1 Humic substances 11

2.2 Plant biostimulants $\quad 11$

2.3 Plant biostimulants humic substances 12

$3 \quad$ Inventory of available humic acid products $\quad 14$

$\begin{array}{llr}4 & \text { Potential uses of humic acid products } & 16\end{array}$

4.1 Potential uses of humic acid products for field crops $\quad 16$

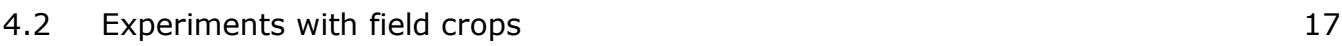

$\begin{array}{lll}4.3 & \text { Application rate } & 18\end{array}$

$5 \quad$ Stakeholder vision $r$

$6 \quad$ Experiments with humic acid products from digestate $\quad 21$

$\begin{array}{lll}6.1 & \text { Onion research } & 21\end{array}$

$\begin{array}{lll}6.2 & \text { Potato field experiment } & 24\end{array}$

$\begin{array}{lll}6.3 & \text { Potato late blight research } & 24\end{array}$

$\begin{array}{llr}7 & \text { Conclusions and recommendations } & 27\end{array}$

$\begin{array}{ll}\text { References } & \mathbf{2 8}\end{array}$

Appendix 1 Scheme for extraction of humic acids $\quad 30$

Appendix 2 Table A2.1 Summary of research on humic acid products. Source: Calvo et al. (2014) $\quad 31$

Appendix 3 Analytical report Koch Eurolab $\quad 35$

$\begin{array}{ll}\text { Appendix } 4 \text { Description of potato experiment } & 40\end{array}$ 



\section{Preface}

In the Netherlands, there are surpluses of manure and digestates/biogas slurries (digested manure and residual flows), which represent a negative value. At the same time, these residual flows contain valuable ingredients for the production of biomass (as raw material for food and feed products), for improving soil quality and for energy production. The number of feasible business cases in which the residual flow is upgraded has so far been limited. This is due both to the efficiency of the technologies used and the legislation and regulations related to the residual flows.

Recent information from research, scientific literature and companies provides new starting points for a biobased valorization of manure/digestate streams and improving the efficiency of anaerobic digestion. The innovative aspect of our research is the cultivation of new types of biomass on the residual flows and the use of the conversion products to improve anaerobic digestion. This involves the use of separated manure and digestate products for the cultivation of mushrooms/fungi, worms, insects, specific bacteria and aquatic biomass. The resulting biomass can be further refined and marketed as food, feed and bio-based feedstock. There are also processed manure and digestate products that are valuable as fertilizer products for soil and plant growth, as substrate for improvement of anaerobic digestion or for export/use besides in agriculture. This gives a new interpretation to obligatory manure processing.

The aim of this project is to further explore and substantiate/test these ideas on lab and practical scale, leading to a proof of principles for new bio-based upgrading methods for manure and digestate that can be used in conjunction to better close cycles and/or sell outside regular agriculture.

Bottlenecks in legislation and regulations are explored and put on the agenda. Key figures are also calculated that are necessary for assessing sustainability (e.g. costs, environmental effects) and for supporting legislation (e.g. minerals, food safety).

The livestock sector gains insight into the possibilities of biobased valorisation and better marketing of their most important residual flows. For the SMEs involved, this research provides proof of principle for their technology and input in their business cases. The combined effects of the technologies provide new knowledge, methods and research directions for science. In a social context, the use and upgrading of manure and digestates in other ways also contributes to the transition to a circular bioeconomy with an efficient and sustainable agri-food sector.

More information:

- http://www.acrres.nl/en/projecten_acrres/biobased-valorization-of-manure-and-digestate/

- Rommie van der Weide: rommie.vanderweide@wur.nl, +31320291631

- Hellen Elissen: hellen.elissen@wur.nl, +31320291223

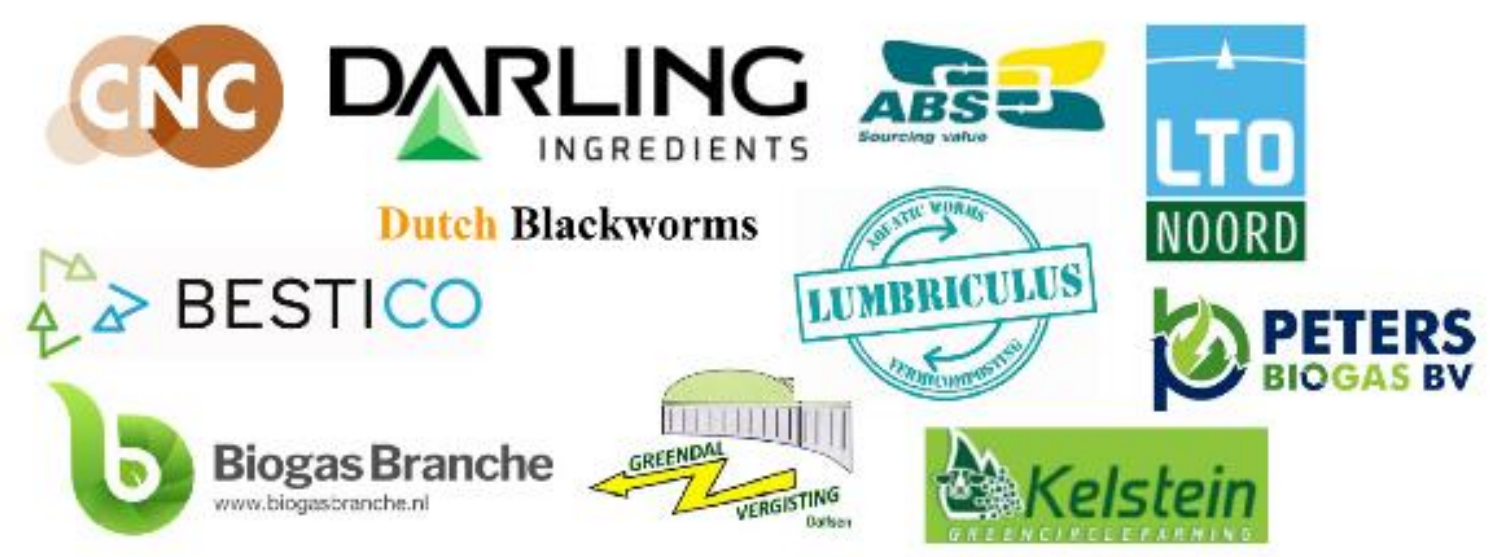




\section{Summary}

The Wageningen Research conducted a Quickscan to examine the prospects for products comprising humic acids, such as the humic acid product produced by Ecoson.

The research questions were:

- What are the characteristics of the humic acid products now on the market?

- Which crops can these humic acid products be used for and what doses and times of application are used?

- What is the use of humic acids in practice?

- Which stakeholders are interested in using humic acid products and what further information and actions are needed?

To answer these research questions, a desk study was carried out, a literature research was conducted and five stakeholders were interviewed, also several field studies were carried out to research the effect of humic acids on crop yield and quality.

Humic and fulvic acids are fractions of organic compounds with similar characteristics, these terms originate from soil science. Humic acid products that are on the market in the Netherlands are derived from brown coal (lignitite/leardonite) or are produced by decolouring drinking water (Vitens). In research also humic acids from compost are used, and the extraction of humic acids from animal manure/digestate by Ecoson is a new source. In terminology humic acids, fulvic acids and humic substances are commonly exchanged and used for marketing purposes.

Humic acids are used as biostimulants and as food and feed additives. Most perspective for the humic acid product from Ecoson is the use as a biostimulant considering the law and regulations for animal manure. There are several mechanisms of humic acids described that can stimulate plant growth. For instance increase of availability of soil phosphorus/nutrients, increase of water holding capacity of the soil, hormonal like reactions in the plant, enhanced growth of root system. A strong variability in the effects of humic acid products on crop growth is found, the effect depends on the source of the humic substances, the environmental conditions, the receiving plant, the dose and the manner in which the humic acid products are applied. On average, yield increases are reported by al kinds of crops (onion, wheat, potato, strawberry, maize, grass, grapes). Field trials conducted in the Netherlands are sparse this might be due to the optimal conditions that already exist.

In literature it was found that application rates used are within the range 1.5 to $20 \mathrm{~kg}$ humic substances/ha. Optimal application rates depend on humic substances product and crop. Application rates of circa $8 \mathrm{~kg}$ humic substances/ha are thought to be an adequate guideline. In the Netherlands grass and maize, followed by potatoes, wheat and sugarbeet are the main crops produced considering use of land. So these the use of humic acids for these crops can lead to a potentially big market for humic acids. If profit per hectare is the main selection criteria red cabbage, strawberries, fruit growing and potatoes are promising for the use of humic acids. These crops represent a smaller market but because of higher profits the use of humic acids can be more economically beneficial.

Several experiments with the humic acid product from Ecoson were conducted. The humic acid product was tested in an onion field trial; no significant positive or negative effect on yield and quality was found. A field trial with potatoes did also give no significant positive or negative effects on yield. For both field experiments disease pressure was registered, but probably due to the hot and dry summers of 2018 and 2019 disease pressure was low. The Humic acids of Ecoson can be sprayed with normal field sprayers in doses of 120 I Humic acids of Ecoson/hectare. Crop spraying with doses 1,5-3 I Humic acids of Ecoson/hectare per spraying (two times spraying) seemed safe for onion, potatoes and tomato plants.

From interviews with stakeholders it was concluded that humic acids will not have an added value for regular cultivation of crops in the Netherlands. Maybe within the biological cultivation of crops the use of humic acids can give an advantage. Only when costs will decrease and additional yields are proven, 
humic acid products can be successful. In soil based horticulture humic substances are used. Maybe a role of humic acids can be the replacement of iron chelates that are now used in the irrigation water in non-soil based horticulture for the complexation of metal ions. These iron chelates are relatively expensive but a stable system is more important than costs of fertilizers. For pear trees the humic acids are advised to use to prevent pear decline. The fruit sector can be a relevant market for humic acids. For all sectors the benefits of humic acids should be proven in field trials (in the Netherlands) to persuade the farmers to start applying them.

Marketing of humic acids requires further proof of product. Field experiments are needed followed by word-of-mouth advertising. Not only the farmers should be persuaded but also the advisors or fertilizer suppliers. 


\section{Introduction}

Wageningen Research aims to develop nature-based processes to increase the value of manure and digestate. Therefore knowledge and power are bundled with a consortium of partners within the project 'Biobased valorisation of manure and digestate'. Darling Ingredients ('DarlingI') is one of the partners and wants to focus on humic acids (humic acid, fulvic acid) extracted from digestate. DarlingI has developed a new biobased technology and is able to extract the humic acids (see Figure 1). DarlingI now wants to explore the market for these products.

The goal of this Quickscan is to examine the prospects for products comprising humic acids, such as that produced by DarlingI.

The research questions are:

- What are the characteristics of the humic acid products now on the market (Chapter 3 )?

- Which crops can these humic acid products be used for and what doses and times of application are used (Chapter 4)?

- What is the use of humic acids in practice (Chapter 5 )?

- Which stakeholders are interested in using humic acid products and what further information and actions are needed (chapter 6)?

To answer these research questions, a desk study was carried out, a literature research was conducted and five stakeholders were interviewed. The effect of humic acid products on the quality and quantity of onions was evaluated in a field study and compared against findings in a field study on potatoes carried out by DarlingI in cooperation with Wageningen Research. Furthermore, a greenhouse trial was conducted to investigate the effect of leaf application of a humic acid product on the development of an important Phythophthora disease.

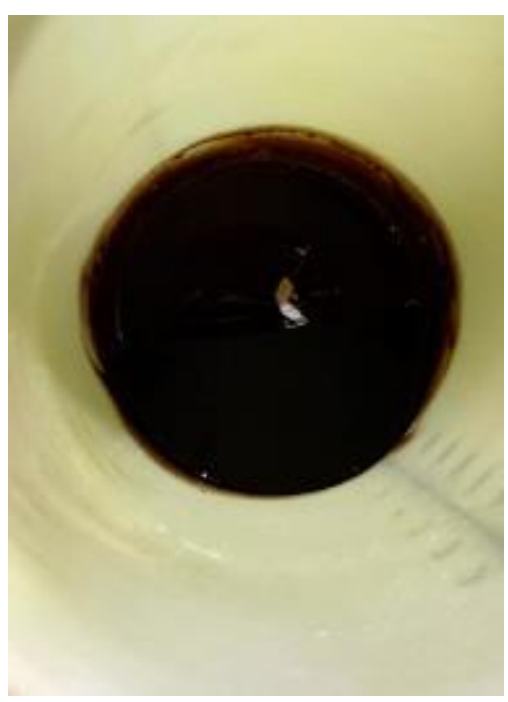

Figure 1.1 Humic acids of Ecoson, an extracted humic acid product developed by DarlingI. Photo: Wageningen Plant Research. 


\section{Information on humic substances}

\subsection{Humic substances}

Soil consists of a mineral fraction, an organic fraction, water and air (soil pores). Soil scientists define a specific group of organic compounds in the soil as humic substances. These include humic and fulvic acids, and also hydrophilic acids and hydrophobic neutral organic matter. Using extraction methods, humic and fulvic acids can be separated out. The components are discriminated by behaviour (for extraction scheme, see Appendix 1 to this report) (Van Zomeren en Comans 2007). These humic and fulvic acids are known to be complex structures of organics with relatively high amounts of aromatic structures, and are also known to be resistant to degradation. It is hypothesised that these compounds are created during degradation processes in the soil, but this hypothesis has been challenged by Lehmann and Kleber (2015), who suggest that the humic and fulvic acids detected in measurements might be an artefact of the analytical process (i.e. that acid and alkaline extraction could induce their creation). However, there is no doubt that some soil characteristics (higher cation exchange capacity (CEC), higher soil water-holding capacity, lower degradation rate of organic matter, lower leaching of nutrients) are associated with higher measured amounts of humic and fulvic acids in the soil.

In the Netherlands, different products based on humic acids and fulvic acids are available. These humic acid-based products are commonly used as a soil improver/plant biostimulant (https://www.triferto.eu/nl ; http://humifirst.be/). Other uses are:

- Feed additive: Agrivalid sells a feed additive containing humic acids and states that cows, pigs and horses can benefit (http://www.agrivalid.eu/nl/sectoren/feed)

- Food additive/health improver: For instance, the company Health Solutions specialises in producing humic and fulvic acids for health and food/feed applications (https://healthsolution.eu/nl/)

- Technical applications/research; Humintech (Germany) produces humic acid-based products for removal of metals from water or concrete liquefier (https://www.humintech.com/industry.html).

\subsection{Plant biostimulants}

The definition of plant biostimulants according to the European Biostimulant Industry Council (EBIC, http://www.biostimulants.eu/, 2016) is:

"Materials which contain substance(s) and/or microorganisms, whose function when applied to plants or the rhizosphere is to stimulate natural processes to enhance/benefit nutrient uptake, nutrient efficiency, tolerance to abiotic stress, and/or crop quality, independent of its nutrient content. Biostimulants have no direct action against pests, and therefore do not fall within the regulatory framework of pesticides."

Biostimulants can have different physiological effects on plants (see Figure 2.1). 


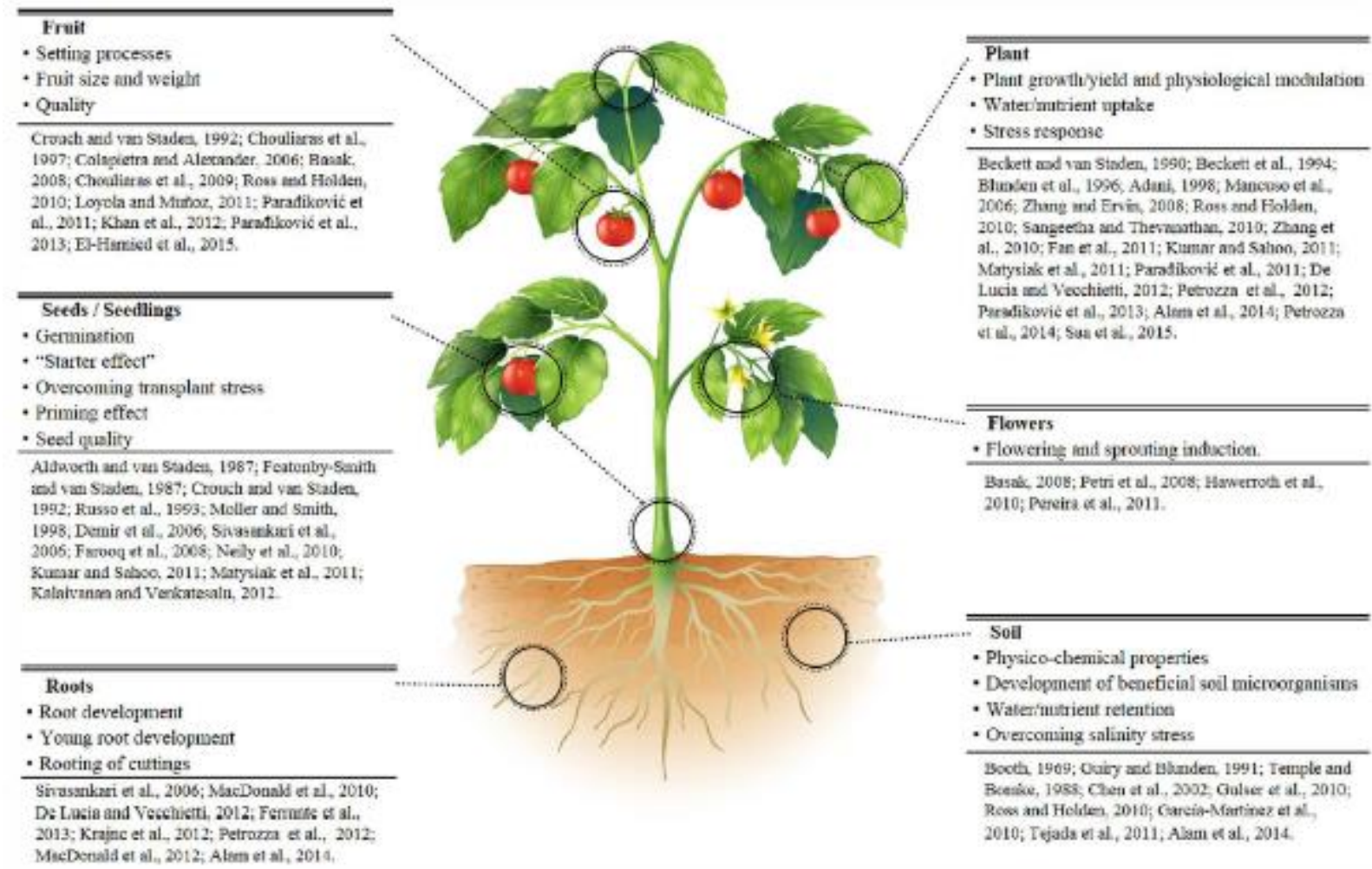

Figure 2.1 Reported examples of the main effects and physiological actions played by plant biostimulants (PBS). Source: Povero G, Mejia JF, Di Tommaso D, Piaggesi A and Warrior P (2016) A systematic approach to discover and characterize natural plant biostimulants. Front. Plant Sci. 7:435. doi: $10.3389 /$ fpls.2016.00435

Du Jardin (2015) categorised plant biostimulants into:

- Humic and fulvic acids

- Protein hydrolysates and other nitrogen-containing compounds

- Seaweed extracts and botanicals

- Chitosan and other biopolymers

- Inorganic compounds

- Beneficial fungi

- $\quad$ Beneficial bacteria

Biostimulants are not captured in EC regulations (either in EC 1107/2009 Plant Protection Products or in EC 2003/2003 Fertilisers). Humic acids of Ecoson, the product developed by DarlingI, is derived from animal manure and will keep the status of animal manure under the current regulations. Animal manure and products from animal manure are not permitted for use as a feed additive under EU Regulation 767/2009, article 6, Appendix 3, $1^{1}$. The main future use of Humic acids of Ecoson is expected to be as a plant biostimulant. Therefore this report focuses on use of humic acid and fulvic acid products (hereafter 'humic acids products') as plant biostimulants, and not in health applications.

\subsection{Plant biostimulants humic substances}

For humic acid products, a series of mechanisms leading to increasing plant growth have been described. These comprise: increased bioavailability and uptake of nutrients as an effect of increased CEC (Du Jardin 2015), increased water-holding capacity of the soil (Piccolo et al. 1996), stimulation of plasma

\footnotetext{
${ }^{1}$ Regulation (EC) No 767/2009 of the European Parliament and of the Council of 13 July 2009 on the placing on the market and use of feed, amending European Parliament and Council Regulation (EC) No 1831/2003 and repealing Council Directive 79/373/EEC, Commission Directive 80/511/EEC, Council Directives 82/471/EEC, 83/228/EEC, 93/74/EEC, 93/113/EC and 96/25/EC and Commission Decision 2004/217/EC (Text with EEA relevance);
}

12 | Report WPR-867 
membrane $\mathrm{H}^{+}$ATPases, increasing nutrient uptake (Du Jardin 2015), hormone-like reactions (suggested by Atiyeh et al. 2002) and various effects on microorganisms (Hasset et al. 1986; Sharif et al. 2002; Siddiqui et al. 2009).

Rose et al. (2014) reported strong variability in the effects of humic acid products and concluded that the effect is dependent on the source of the humic substances, the environmental conditions, the receiving plant, the dose and the manner in which the humic acid products are applied. Du Jardin (2015) suggested that the different results of studies can also be (partly) attributed to the complex dynamics of humic and fulvic acids in the soil by forming supramolecular colloids, influenced by exudates of plant roots. Rose et al. (2014) carried out a meta-analysis of published studies on humic acid products and estimated an average positive effect on plant yield of $15-25 \%$. Those authors also identified the most important factors impacting the effect of humic acid products to be: the source of the humic/fulvic acids, plant type and stress conditions.

Humic and fulvic acids are extracted from different sources: peat, brown coal (lignite/leonardite), compost and soil (Du Jardin 2015). Relatively new sources are groundwater (Vitens), liquid manure (DarlingI) and wastewater (Stichting Toegepast Onderzoek Waterbeheer (STOWA)).

Humic acid products as a plant biostimulant are used in different forms: solution, powder, coating of artificial fertiliser and seed coating. Note that humic acid products are also present naturally in compost and animal manure.

For this research it is important to understand that humic acids and fulvic acids are fractions of organic compounds with similar characteristics and that these terms originate from soil science, the composition of humic acids can differ between different sources. In terminology humic acids and humic substances are commonly exchanged and used for marketing. Effects measured with humic substances differ because of different circumstances, overall positive effects on plant growth are found. 


\section{Inventory of available humic acid products}

The properties of three humic acid products available for use as a biostimulant, including Humic acids of Ecoson, are shown in Table 3.1. The focus is on their biostimulant function because this application is the only one available for Humic acids of Ecoson under current EU regulations. As can be seen from Table 3.1, for most products only minimal data on their properties are published on websites and in scientific articles. Although commercial claims about these products can be found, the analytical background is generally not presented. Based on these minimal data presented in table 3.1 the concentrations of humic and fulvic acids in Humic acids of Ecoson are lower than in the other available products. This is not a problem for their effect as a biostimulant, because all products are diluted when applied, but it means that the transport costs can be higher for Humic acids of Ecoson. Compared with the product Humic, the amounts of salts in Humic acids of Ecoson are in the same range (based on the limited data in Table 3.1). The market value of the products will be set based on field trials and the experiences of users. Moreover, as stated in Chapter 2, the quality of the humic and fulvic acids can differ between products.

In order to be able to compare more parameters of the humic acid products a sample of Humic acids Ecoson and another product on the market 'product $X$ ' were analysed by Koch-Eurolab. In table 3.2 the results of this analyses is shown (see also appendix 4 ).

The amounts of humic acids and fulvic acids measured are much lower (roughly 3 times) than the amounts expected (table 3.1 and 3.2). Causes of this discrepancy can be differences in practise of analytical methods or differences in quality between badges of humic acids. The test was only performed on one sample per product. So statistically the result can only be used as a indication of the content of the humic acid products.

The product of Ecoson has got much higher amounts of Copper, Nickel and Zinck than the Product X. These high levels of metals might become a problem if new European legislation is made about biostimulants.

For Product $X$ remarkable high levels of Phosphor, Potassium and Sodium were reported, these levels were also higher than found in the Ecoson product ( $P$ factor $15 \mathrm{~K}$ factor $5 \mathrm{Na}$ factor 5 ). On the other hand nitrogen is a factor 9 higher in the Ecoson product. 
Table 3.1 Available humic acid products in the Netherlands, composition according to companies

\begin{tabular}{|c|c|c|c|}
\hline Product name: & Humic acids Ecoson ${ }^{1}$ & $\begin{array}{l}\text { HumiFirst }{ }^{2} \\
\text { DRIP }\end{array}$ & Humic $^{3}$ \\
\hline Manufacturer (source) & $\begin{array}{l}\text { Ecoson } \\
\text { (animal manure) }\end{array}$ & $\begin{array}{l}\text { Tradecorp } \\
\text { (lignite) }\end{array}$ & $\begin{array}{l}\text { Vitens/Triferto } \\
\text { (drinking water) }\end{array}$ \\
\hline Price (euro/L) & $\mathrm{nb}$ & 4 & \\
\hline Price (euro/g) & - & - & - \\
\hline Use & Soil improver & Soil improver & Soil improver \\
\hline Dry matter content (\%) & $19-21$ & & 22 \\
\hline $\begin{array}{l}\text { Organic matter conten } \\
\text { (\% of dry matter) }\end{array}$ & t80 & & 12 \\
\hline Humic acids $(\mathrm{g} / \mathrm{kg})$ & 50 & 64 & 250 \\
\hline Fulvic acids $(\mathrm{g} / \mathrm{kg})$ & 19 & 192 & \\
\hline $\mathrm{pH}$ & $8.8-9.2$ & 7 & 8.1 \\
\hline$N(g / L)$ & 18 & & \\
\hline$\underline{P}\left(\mathrm{P}_{2} \mathrm{O}_{5}\right)(\mathrm{g} / \mathrm{L})$ & 1.3 & & \\
\hline $\mathrm{K}(\mathrm{g} / \mathrm{kg})$ & 11 & & \\
\hline $\mathrm{Cl}(\mathrm{g} / \mathrm{kg})$ & 0.5 & & $2.4($ as $\mathrm{NaCl})$ \\
\hline $\mathrm{Na}(\mathrm{g} / \mathrm{kg})$ & 3.4 & & $2.4($ as $\mathrm{NaCl})$ \\
\hline $\mathrm{Cd}(\mathrm{mg} / \mathrm{kg})$ & $<0.1$ & & \\
\hline $\mathrm{Cu}(\mathrm{mg} / \mathrm{kg})$ & 37 & & \\
\hline $\mathrm{Pb}(\mathrm{mg} / \mathrm{kg})$ & $<2$ & & \\
\hline $\mathrm{Zn}(\mathrm{mg} / \mathrm{kg})$ & 119 & & \\
\hline
\end{tabular}

Table 3.2 Results chemical analyses Koch-Eurolab Humic acids Ecoson and product X. In gram per $\mathrm{kg}$ product or in milligram per kg dry matter

\begin{tabular}{lll} 
Product name: & $\begin{array}{c}\text { Humic acids } \\
\text { Ecoson }\end{array}$ & Product X \\
Dry matter content $(\mathrm{g} / \mathrm{kg})$ & 122 & 290 \\
\hline Organic matter content $(\mathrm{g} / \mathrm{kg})$ & 70.4 & 137 \\
\hline Humic acids $(\mathrm{g} / \mathrm{kg})$ & 10.5 & 6 \\
\hline Fulvic acids $(\mathrm{g} / \mathrm{kg})$ & 2.4 & 13.9 \\
\hline $\mathrm{pH}$ & 8.4 & 6.83 \\
\hline $\mathrm{N}(\mathrm{g} / \mathrm{kg})$ & 12.4 & 1.4 \\
\hline $\mathrm{P}\left(\mathrm{P}_{2} \mathrm{O}_{5}\right)(\mathrm{g} / \mathrm{kg})$ & 2.0 & 31.2 \\
\hline $\mathrm{K}(\mathrm{g} / \mathrm{kg})$ & 9.4 & 50.3 \\
\hline $\mathrm{Cl}(\mathrm{g} / \mathrm{kg})$ & & 16 \\
\hline $\mathrm{Na}(\mathrm{g} / \mathrm{kg})$ & 3.4 & \\
\hline $\mathrm{Cd}(\mathrm{mg} / \mathrm{kg} \mathrm{dm})$ & & 0.1 \\
\hline $\mathrm{Cu}(\mathrm{mg} / \mathrm{kg} \mathrm{dm})$ & 1.0 & 6.9 \\
\hline $\mathrm{Ni}(\mathrm{mg} / \mathrm{kg} \mathrm{dm})$ & 605 & 6.6 \\
\hline $\mathrm{Pb}(\mathrm{mg} / \mathrm{kg} \mathrm{dm})$ & 110 & 1.7 \\
\hline $\mathrm{Zn}(\mathrm{mg} / \mathrm{kg} \mathrm{dm})$ & 4 & 22 \\
\hline
\end{tabular}




\section{$4 \quad$ Potential uses of humic acid products}

\subsection{Potential uses of humic acid products for field crops}

Calvo et al. (2014) inventoried different possible agricultural uses of humic acid products. A table from Calvo et al. (2014) that summarises almost 50 studies (1980 to 2013) on the use of humic acid products in different cultivations can be found in Appendix 2. Based on that review, it can be concluded that many scientific peer-reviewed studies have been conducted to examine the effects of humic acid products on plant growth, but many of these studies have been carried out in the laboratory or on pot plants in growth chambers. The effects observed in these conditions can be very high and not representative of the practical situation. Therefore literature about field studies was collated and is summarised in Table 4.1. Humic acid products are applied by foliar spraying and soil application, and positive and negative results have been found for both forms of application. Application rates used in field experiments are within the range 1.5 to $20 \mathrm{~kg}$ humic substances/ha. In Table 4.2 for the selected crops, the number of hectares and the average profit per hectare in the Netherlands is also included, to give an indication of the possible market and possible economic effect for commercial humic acid products in the Netherlands.

Table 4.1 Different uses of humic acid products for field crops world-wide and in the Netherlands

\begin{tabular}{|c|c|c|c|c|c|}
\hline Crop & $\begin{array}{l}\text { Appl- } \\
\text { ication }\end{array}$ & $\begin{array}{l}\text { Application } \\
\text { rate (kg } \\
\text { humic/fulv } \\
\text { ic acid/ha) }\end{array}$ & $\begin{array}{l}\text { Study } \\
\text { conditions, } \\
\text { country }\end{array}$ & $\begin{array}{l}\text { Effect (humic } \\
\text { substances) }\end{array}$ & References \\
\hline Onion & Soil & 20 & Field, India & Yield $+11 \%$ & Sangeetha and Singaram (2007) \\
\hline Sugar beet & Foliar & - & Field Egypt & $\begin{array}{l}\mathrm{HA}^{\#} \text { Yield }+14 \% \\
\mathrm{FA}^{\# \#} \text { Yield }+23 \%\end{array}$ & Hassanin et al. (2016) \\
\hline Wheat & & & & & $?$ \\
\hline Common bean & Foliar & - & Field, Egypt & Yield $+10 \%$ & Ibrahim et al. (2012) \\
\hline Broccoli & Soil & - & Field, Egypt & Yield $+15 \%$ & Selim and Mosa (2012) \\
\hline \multirow[t]{2}{*}{ Potato } & Soil & 8.2 and 16.4 & Field, Egypt & $\begin{array}{l}\text { Water stress: no effect. } \\
\text { Without water stress: } \\
\text { increased yield }\end{array}$ & Selim et al. (2012) \\
\hline & Soil & 3.9 to 8.25 & Field, Belgium & Yield +13 and $+17 \%$ & Verlinden et al. (2009) \\
\hline Grassland & Soil & 3.5 to 15 & Field, Belgium & Yield -8 and $+10 \%$ & Verlinden et al. (2009) \\
\hline \multirow[t]{2}{*}{ Maize } & Soil & 8.25 & Field, Belgium & Yield 0 and $+2 \%$ & Verlinden et al. (2009) \\
\hline & Soil (row) & 1.5 & Field, Belgium & Yield +1 and $+3 \%$ & Verlinden et al. (2009) \\
\hline \multirow[t]{2}{*}{ Strawberry } & Foliar & - & Field, Italy & Yield $-23 \%$, better quality & Neri et al. (2002) \\
\hline & Soil & - & $\begin{array}{l}\text { Greenhouse, } \\
\text { Iran }\end{array}$ & Yield +47 and $+103 \%$ & Escghi et al. (2015) \\
\hline Fruit growing & & & & & ? \\
\hline
\end{tabular}

\#HA=humic acid, \#\#FA= fulvic acid, - rate per hectare unknown, ? no relevant article found. 
Table 4.2 Hectares of field crops in the Netherlands and average unit revenues and yields.

\begin{tabular}{|c|c|c|c|c|c|}
\hline Crop & $\begin{array}{l}\text { Effect Humic } \\
\text { substances }\end{array}$ & 1000 ha $*$ & $\begin{array}{l}\text { Revenue } \\
\text { Euro/hectare** }\end{array}$ & $\begin{array}{l}\text { Profit } \\
\text { Euro/hectare** }\end{array}$ & $\begin{array}{l}\text { Yield } * * \\
\text { Tonnes / hectare }\end{array}$ \\
\hline Onion & Yield $+11 \%$ & 25 & $5,000-5,950$ & $2,897-2,107$ & $50.5-59.5$ \\
\hline Sugar beet & $\begin{array}{l}\mathrm{HA}^{\#} \text { Yield }+14 \% \\
\mathrm{FA}^{\# \#} \text { Yield }+23 \%\end{array}$ & 71 & $3,435-3,831$ & $2,143-2,481$ & $75.1-83.7$ \\
\hline Wheat & $?$ & 128 & $1,885-2008^{\#}$ & $1,118-1,170^{\#}$ & $8.5-8.9^{\#}$ \\
\hline Common bean & Yield $+10 \%$ & 1 & 2,345 & 1,134 & 3.3 \\
\hline Broccoli & Yield $+15 \%$ & $\mathrm{nb}$ & $16,720-15,200$ & 14,113 & 30,400 (numbers) \\
\hline Potato & $\begin{array}{l}\text { Yield }+0 \text { and }+13 \text { and } \\
+17 \%\end{array}$ & 157 & $7,300-11,172$ & $4,442-7,589$ & $39.9-52.5$ \\
\hline Grassland & Yield -8 and $+10 \%$ & 936 & $2,736 * * *$ & $1,964 * * *$ & $7,6 \mathrm{dm} * * *$ \\
\hline Maize & Yield 0 and $+3 \%$ & 206.9 & 2,063 & 1,095 & $16.5 \mathrm{dm}$ \\
\hline Strawberry & $\begin{array}{l}\text { Yield }-23 \%+47 \text { and } \\
+103\end{array}$ & 2.8 & $38,285^{\# \#}$ & $20,473^{\# \#}$ & $20,1^{\# \#}$ \\
\hline Fruit Growing & $?$ & 20 & $27,000^{\# \# \#}$ & $5,000^{\# \# \#}$ & $40^{\# \# \#}$ \\
\hline Red Cabbage & $?$ & 0,5 & 27,500 & 19,238 & 55,0 \\
\hline
\end{tabular}

*From CBS statline amount of hectares cultivated in the Netherlands in 2016. ? no relevant article found. ** source KWIN AGV 2018. *** Data applies for seed and hay production, grassland used for dairy cattle will have a higher production of dry matter, but a lower financial yield. dm = dry matter. \#Based on Winter wheat. \#\# Based on open field cultivation. \#\#\# Calculated values from data available at www.agrimatie.nl.

\subsection{Experiments with field crops}

As can be seen from the area used for different crops (Table 4.1), grass, maize, potato and wheat are the main crops in the Netherlands. Verlinden et al. (2009) investigated the effect of humic acid products on maize, grass and potatoes in Belgium and their results can be representative (in terms of climate, soil use, soil quality) for the situation in the Netherlands. Their experiments were carried out in field situations and in pot experiments. Only results of the field experiments are summarised in this report. The product HumiFirst was used for the experiments and a dose of $8.25 \mathrm{~kg} /$ hectare was applied. Two forms were tested: liquid humic/fulvic acids and incorporated humic/fulvic acids (fertiliser coated with humic/fulvic acids).

For grassland (permanent and new grassland), Verlinden et al. (2009) found that the first yield after humic acid application was higher than in the control (12-16\% for liquid application and $3-42 \%$ for humic acid-incorporating product. For the whole season, grass yields in these two treatments were similar to that in the control $(-8 \%$ to $+10 \%$ in yield, respectively). For both broadcast and row application, only small effects were obtained. According to Verlinden et al. (2009), this can be due to the high nutrient levels in the soil. The highest increase in yield was obtained for potatoes $(+13$ and $+17 \%$ for low and high application rate, respectively). Based on the results of statistical analysis, Verlinden et al. (2009) concluded that the increases and decreases in yield on a yearly basis were not statistically significant.

The study by Selim et al. (2012) referred to in Table 4.1 was conducted in Egypt and the results are thus less representative for the Netherlands. Under water stress conditions, application of humic acid products in that study did not have an effect on potato tuber yield, while under normal water conditions application of humic acid products led to an increase of $19 \%$ in tuber yield, with the highest yield for a high application rate of $16.4 \mathrm{~kg}$ humic acids/hectare.

For wheat, no relevant published field study was found. However, a summary of five studies about humic acid products and wheat (pot, growth chamber and hydroponic studies) is presented in Appendix 2. Positive results on growth were found in these studies, but a field test in one study found no increase or a decrease in the growth of wheat. 
The crops sugar beet, onion and strawberries and several vegetables are also grown on an reasonable area in the Netherlands and, because of their higher selling price, information stated in Table 4.1 for these crops could also be very relevant. The studies summarised in Table 4.1 found positive effects of humic acid products on yield for all these crops. However, it should be borne in mind that these studies were conducted under different conditions from those in the Netherlands.

Tomatoes, peppers and cucumbers cultivated in greenhouses are other potential crops on which humic acid products can be used. The different studies listed in the table in Appendix 2 show positive results in glasshouse production of these crops following addition of humic acid products to the nutrient solution.

Literature research about the use of humic substances in fruit growing was found (for instance apples, pears, olives and abricots). Some studies showed benefits for fruit growing, but set ups of these experiments did not give relevant information for the Dutch situation.

\subsection{Application rate}

Dobbs et al. (2010) found that the optimal dose varied depending on the humic acid/s used and also the plants to which they were applied. There is an indication that if growth-stimulating hormones are available above a certain level, plant growth will decrease following application of humic acid products. This might be the reason why there is an optimal dose for humic acid products.

For HumiFirst, a dose of 50 litres per hectare is advised for soil application. This is equivalent to an active dose of $8.3 \mathrm{~kg}$ humic/fulvic acids per hectare. This advice from the manufacturer of HumiFirst is in line with the dosages reported in studies involving field experiments (see Table 4.1). No recent advice on application rates were found for the product Humic.

The effect of yearly application of humic acid products to the soil on crop yields and whether application rates should be altered with yearly use remain to be determined.

If we do a quick and dirty calculation based on assumptions: a sandy soil in the Netherlands with $5 \%$ soil organic matter, 5 gram (Spijker et al, 2009) humic substances per kg soil, an A horizon of $0.25 \mathrm{~m}$ and a soil density of $1.6 \mathrm{~kg} / \mathrm{litre}$.

In this case per $\mathrm{m}^{2}$ soil $2 \mathrm{~kg}$ humic substances are present in the A horizon $=>5 *(1 * 1 * 0.25 * 1.6)$

Applying a dose $8 \mathrm{~kg}$ of humic acids per hectare gives a doses of $0.0008 \mathrm{~kg} / \mathrm{m}^{2}$. So this is circa $0.04 \%$ of the humic acids content already present in the soil.

Based on this quick and dirty calculation the amounts of humic substances added to the soil is low compared to the humic substances already present in the soil. 


\section{$5 \quad$ Stakeholder vision}

Five experts were interviewed to gain more information about the market conditions of humic acids in the Netherlands:

- $\quad$ Luuk Hagting (Agrifirm); fertilizers and biostimulants

- Wim Voogt (WUR); horticulture substrate cultivation

- Wim van Dijk (WUR); field crops

- $\quad$ Rien van der Maas (WUR); fruit growing

- Chris van Laarhoven (Tuinbouw advies); horticulture soil cultivation

The interviewed persons are not experts on humic acids but are well known with practices within their sector.

\section{Field Crops}

Known is that the humic and fulvic acids are produced with the degradation of organic materials. The humic acids have chelating properties and phosphate and other micro nutrients are more available for the crops. Also soil structure and water holding capacity of the soil are increased with humic acids. Brands that are known are Humifirst (Tradecorp) and Humic (Triferto).

The use of humic acid products in the Netherlands in field crops is low. A hypotheses is that the crops will especially benefit from humic acid products if the circumstances are suboptimal. In the Netherlands agriculture and fertilization is optimized. Maybe this is the reason why the positive effects of humic acids are not found in general during field trials in the Netherlands. In tests with other soil improvers like black carbon also less effect was found than during experiments in other countries. Also animal manure and other organic fertilizers or organic soil conditioners are used, which can also have (potential) humic acid in it. If humic acid products are used it can be as a liquid, a solid or as a coating.

An important factor to explain the use of humic acids is the relation between the fertilizer dealer/advisor and the farmer rather than crop use, soil type or region. So marketing of the dealer/advisor and experiences of a farmer with the product are key factors. The cost benefits are thought to be negative within the Netherlands because of the already optimal growing conditions (it will cost more to purchase and apply the humic acid products than the yield and profit will increase).

For regular cultivation of field crops in the Netherlands the experts think that humic acid will not have an added value. Maybe within the biological cultivation of crops the use of humic acids can give an advantage. Only when costs will decrease and additional yields are proven, humic acid products can be successful.

\section{Horticulture}

In the Netherlands Humic acids are almost not used in substrate horticulture, but in soil based horticulture they are. Main reasons not to use humic acids in substrate horticulture is that humic acids can lead to blockage and formation of biofilms in the irrigation system. And 85 to $90 \%$ of the horticulture is done on substrates with drip irrigation. Also the effectiveness is not well proven and fertilization costs are secondary to the reliability of the fertilizer.

In soil based horticulture doses of 10-25 Itr /ha are used and well known products are Pow Humus and Humifirst. Pow Humus puts a lot of effort in creating a market for the humic substances but without success. Liquid products are preferred because these are easy to use also solid humic acid products are used. Important is also that it is thought that different humic acid products have different effectiveness and quality. The humic acids are used to improve the soil conditions by increasing the amount of fungi in the soil, to buffer an excess of Potassium or Sodium (resulting in a better uptake of Calcium and Manganese) and increases the bioavailability of Phosphate.

Maybe a role of humic acids can be the replacement of iron chelates that are now used in the irrigation water for the complexation of metal ions. These iron chelates are relatively expensive but a stable system is more important than costs of fertilizers.

\section{Fruit}

Humic acids are used for fruit trees. Humic acids are advised for pear trees by Fruit Consult and CAF (Centrale Adviesdienst Fruitteelt). It is advised to give a liquid fertilizer product of ammonia nitrate, iron (chelates) and humic acid for pear trees just before harvest. The humic acids are supposed to increase the roots system (and prevent Pear Decline) and can have an effect on the quality of the pears. In this 
particular matter the Humic acids are advised and therefore used. For pears also benefits in pear color were determined by research in the Netherlands. A doses of $15 \mathrm{ml}$ humifirst dissolved in 10 liters of water is advised especially for trees that show deficiency of nutrients. If all trees are treated a doses of up to 40 liters can be used based on this advice.

So the fruit sector can be a market for humic acids.

For all sectors the benefits of humic acids should be proven in field trials (in the Netherlands) to persuade the farmers to start applying them. Mikkelsen (2005) also concluded; on farm field trials are needed to determine effectiveness. 


\section{Experiments with humic acid products from digestate}

\subsection{Onion research}

\section{Introduction}

In 2017, 2018 and 2019, a test on various potassium fertilisation strategies was carried out at the Wageningen Research test farm in Lelystad. The treatments involved varying the dose and application pattern (single, split-dose) of the potassium and method of application (via the soil or as a foliar treatment). An additional treatment was included to test the effects of the humic acid of Ecoson for 2018 and 2019. This was sprayed over the plants or applied to the soil. The effect on the resilience of the plants and quality of the onion bulbs was evaluated. A few rows of onions per treatment were sown at such a high density that plant diseases were provoked. The research is described in detail in Van Geel et al., 2020a en 2020b the reports are in Dutch and anonymised. In the paragraph below a summary of this research is given. The for humic acid relevant treatments are shown in table 1.

Table 6.1 Objects Humic acid product

\begin{tabular}{|c|c|c|c|}
\hline $\begin{array}{l}\text { Object } \\
2018\end{array}$ & $\begin{array}{r}\text { Object } \\
2019\end{array}$ & Description & \\
\hline A & $A B$ & Reference untreated & Fertilizer NPK \\
\hline $\mathrm{N}$ & C & $\begin{array}{l}\text { Humic acid product } \\
\text { Soil application: }\end{array}$ & $100 \mathrm{~L} / \mathrm{ha}$ before sowing \\
\hline 0 & $\mathrm{D}$ & $\begin{array}{l}\text { Humic acid product } \\
\text { Foliar spraying: }\end{array}$ & $\begin{array}{l}\text { Foliar } 1,5 \mathrm{~L} / \mathrm{ha} \text { just before bulbing and two weeks } \\
\text { later second treatment }\end{array}$ \\
\hline$P$ & $E$ & $\begin{array}{l}\text { Humic acid product } \\
\text { Foliar spraying: }\end{array}$ & $\begin{array}{l}\text { Foliar } 3 \mathrm{~L} / \text { ha just before bulbing and two weeks } \\
\text { later second treatment }\end{array}$ \\
\hline
\end{tabular}

\section{Results}

The plant density in 2018 was somewhat low with on average 76 plants per $\mathrm{m}^{2}$ (goal is 90 plants per $\mathrm{m}^{2}$ ). The drought during the summer of 2018 can be the explanation for this, although because of irrigation of the crop the yield was not considered bad (40 ton/ha). Size of the onions was 35-60 mm which is rather small. No significant differences were observed during the growing season of 2018 between the different treatments (crop status, crop regularity, colour of the crop and foliage falling and dying) (see table 6.2). During the dying process of the leaves Stemphylium and Fusarium were present. But no significant differences in damage between the treatments were observed.

Because no significant positive or negative effects on growth and quality were observed in 2018 also no significant higher or lower yields and market value were registered (table 6.3).

In 2019 on average 81 plants per $\mathrm{m}^{2}$ were present. Only object C (Soil application of humic acids) a significantly lower plant density was determined ( 75 plants per $\mathrm{m}^{2}$ ). During growing season no other significant differences in crop condition between the objects was observed. Leaf diseases were low as was also the case in 2018 , this was probably due to the dry summers. The crop yield was higher than in 2018 (63 ton/ha). No significant differences were observed during storage and market value between the different objects. The harvested amount of bulbs in 2019 was higher than in 2018 but storage of the bulbs did have more effect on the hardness of the bulbs in 2019. 


\begin{tabular}{|c|c|c|c|c|c|}
\hline Datum & Crop status & Crop regularity & Colour crop & $\begin{array}{c}\text { Falling of the } \\
\text { leaves }\end{array}$ & $\begin{array}{c}\text { Percentage } \\
\text { green leaf }\end{array}$ \\
\hline \multicolumn{6}{|l|}{2018} \\
\hline 15 June & 7,5 & 8,0 & & & \\
\hline 29 June & 6,3 & 7,3 & & & \\
\hline 13 July & 6,8 & 7,8 & 7,9 & & \\
\hline 27 July & 7,2 & 7,8 & 8,8 & & \\
\hline 13 Aug & & & & $75 \%$ & $74 \%$ \\
\hline 24 Aug & & & & $94 \%$ & $50 \%$ \\
\hline 31 Aug & & & & $97 \%$ & $25 \%$ \\
\hline \multicolumn{6}{|l|}{2019} \\
\hline 1 juli & 7 & & & & \\
\hline 15 juli & 8,8 & & & & \\
\hline 22 juli & 9,0 & & & & \\
\hline \multicolumn{6}{|l|}{29 juli } \\
\hline 5 aug & & & & $30 \%$ & $90 \%$ \\
\hline 12 aug & & & & $95 \%$ & $90 \%$ \\
\hline 26 aug & & & & & $48 \%$ \\
\hline 2 sep & & & & & $23 \%$ \\
\hline
\end{tabular}

Tabel 6.3 Yield after harvest, storage efficiency, and market value 2018

\begin{tabular}{|c|c|c|c|c|c|}
\hline \multirow{2}{*}{$\begin{array}{l}\text { Object } \\
2018 \\
\end{array}$} & \multirow[t]{2}{*}{ Description } & \multicolumn{2}{|c|}{ Yield (ton/ha) } & \multirow{2}{*}{$\begin{array}{c}\text { Market } \\
\text { (ton/ha) }\end{array}$} & \multirow[t]{2}{*}{ Storage efficiency } \\
\hline & & Fresh & Dry matter & & \\
\hline A & Reference & 47,4 & 7,7 & 38,5 & $81 \%$ \\
\hline $\mathrm{N}$ & Humic acid Soil & 49,0 & 7,5 & 40,6 & $83 \%$ \\
\hline $\mathrm{O}$ & $\begin{array}{l}\text { Humic acid } \\
\text { Foliar } 1\end{array}$ & 45,4 & 7,1 & 35,6 & $78 \%$ \\
\hline$P$ & $\begin{array}{l}\text { Humic acid } \\
\text { Foliar } 2\end{array}$ & 48,4 & 7,5 & 39,4 & $81 \%$ \\
\hline Fpr. & & n.s. & n.s. & n.s. & n.s. \\
\hline Object & Description & Yi & ton/ha) & Market & Storage efficiency \\
\hline 2019 & & Fresh & Dry matter & (ton/ha) & \\
\hline$A B$ & Reference & 76,9 & 11,3 & 64,1 & $83 \%$ \\
\hline C & Humic acid Soil & 75,3 & 10,8 & 61,9 & $82 \%$ \\
\hline $\mathrm{D}$ & $\begin{array}{l}\text { Humic acid } \\
\text { Foliar } 1\end{array}$ & 76,3 & 10,6 & 62,8 & $82 \%$ \\
\hline$E$ & $\begin{array}{l}\text { Humic acid } \\
\text { Foliar } 2\end{array}$ & 76,6 & 10,6 & 64,2 & $84 \%$ \\
\hline Fpr. & & n.s. & n.s. & n.s. & n.s. \\
\hline
\end{tabular}

Another important parameter that was measured is the hardness of the bulbs. Also for the hardness no significant differences between the treatments were observed (table 6.4). 
Table 6.4. Hardness before and after storage (index) 2018

\begin{tabular}{llcc}
\hline Object & Desciption & Before storage & After storage \\
\hline $\mathbf{2 0 1 8}$ & & & \\
\hline A & Reference & 100 & 88 \\
N & Humic acid Soil & 101 & 93 \\
O & Humic acid Foliar 1 & 96 & 89 \\
P & Humic acid Foliar 2 & 103 & 88 \\
F pr. & & $n . s$. & $n . s$. \\
2019 & & & \\
AB & Reference & 99 & 59 \\
C & Humic acid Soil & 104 & 61 \\
D & Humic acid Foliar 1 & 98 & 59 \\
E & Humic acid Foliar 2 & 101 & 59 \\
F pr. & & $n . s$. & $n . s$. \\
\hline
\end{tabular}

In table 6.5 the mineral uptake of the union bulb per hectare is shown. There are no significant differences between the uptake of minerals for the different treatments.

Table 6.5. Mineral uptake of the onions $(\mathrm{kg} / \mathrm{ha}) 2018$

\begin{tabular}{lllccccc}
\hline Object & Description & $\mathbf{N}$ & $\mathbf{P}_{\mathbf{2}} \mathbf{O}_{\mathbf{5}}$ & $\mathbf{K}_{\mathbf{2}} \mathbf{O}$ & $\mathbf{S O}_{\mathbf{3}}$ & $\mathbf{M g O}$ & $\mathbf{C a O}$ \\
\hline $\mathbf{2 0 1 8}$ & & & & & & & \\
\hline A & Reference & 123 & 54 & 134 & 89 & 11 & 80 \\
N & Humic acid Soil & 123 & 52 & 130 & 89 & 11 & 90 \\
O & Humic acid Foliar 1 & 116 & 52 & 130 & 84 & 10 & 85 \\
P & Humic acid Foliar 2 & 121 & 55 & 135 & 85 & 11 & 79 \\
F pr. & & n.s. & n.s. & n.s. & n.s. & n.s. & n.s. \\
$\mathbf{2 0 1 9}$ & & & & & & & \\
AB & Reference & 161 & 61 & 171 & 98 & 18 & 9,7 \\
C & Humic acid Soil & 149 & 58 & 158 & 87 & 17 & 9,2 \\
D & Humic acid Foliar 1 & 148 & 56 & 158 & 89 & 17 & 9,0 \\
E & Humic acid Foliar 2 & 155 & 59 & 162 & 94 & 16 & 8,4 \\
F pr. & & n.s. & n.s. & n.s. & n.s. & n.s. & n.s. \\
\hline
\end{tabular}

Between the different treatments no significant differences were observed. This can partly be explained by the dry summer of 2018 the crop was hardly influenced by diseases (less than $1 \%$ foliar diseases were observed). For 2019 also no significant differences were observed between the different treatments.

The results of both years were statistically analysed. Some significant differences were found but they were mostly related to the other tested product, and these differences were too small or unimportant to be worth consideration..

The weather during the experiment in 2018 was for Dutch conditions not representative for average summers. It was typed as a hot and dry summer, this certainly effected the experiment. The fact that little diseases were registered at the high density rows of the control confirms this. In 2019 the weather was less different from average but still typed as a hot and dry summer. 


\subsection{Potato field experiment}

In 2018, an experiment with potatoes and addition of humic acid product was conducted in a potato field comprising 1 hectare. A brief description of the experiment is presented in Appendix 4. In brief, potatoes were grown with and without soil addition of the humic acid product of Ecoson at a rate of 120 I per hectare. Growth of the tubers was determined by visual inspection. Because of the dry summer of 2018, growth of the tubers was slow and the farmer and PEKA KROEF decided that sampling before harvest was not needed. Visually, there was no difference between development of tubers with or without humic acid product treatment

The research conducted was very basic but it can be concluded that:

- Humic acid product of Ecoson can be applied with normal tillage machinery

- In 2018, adding a humic acid product did not lead to differences in potato tuber growth, but this was only determined by a quick visual inspection.

In 2019 this research was not repeated.

\subsection{Potato late blight research}

\section{8 pot experiment tomatoes}

A pot experiment with tomato plants was carried out to investigate the effect of humic acid product on late blight disease development. It was a first explorative study to. The tomato plants were grown in a greenhouse and were inoculated with late blight. The plants were then sprayed with different doses of humic acid product, another tested product and a fungicide. The percentage of necrotic foliage on four leaves per plant was estimated visually. The main conclusions of the research are:

- $\quad$ No phytotoxicity was observed and the products used were safe for crops

- Late blight severity was significantly lower in all treatments tested than in the untreated control, regardless of the dose rate or the spraying interval

- The fungicide product showed significantly greater efficacy in controlling late blight disease than the other treatments.

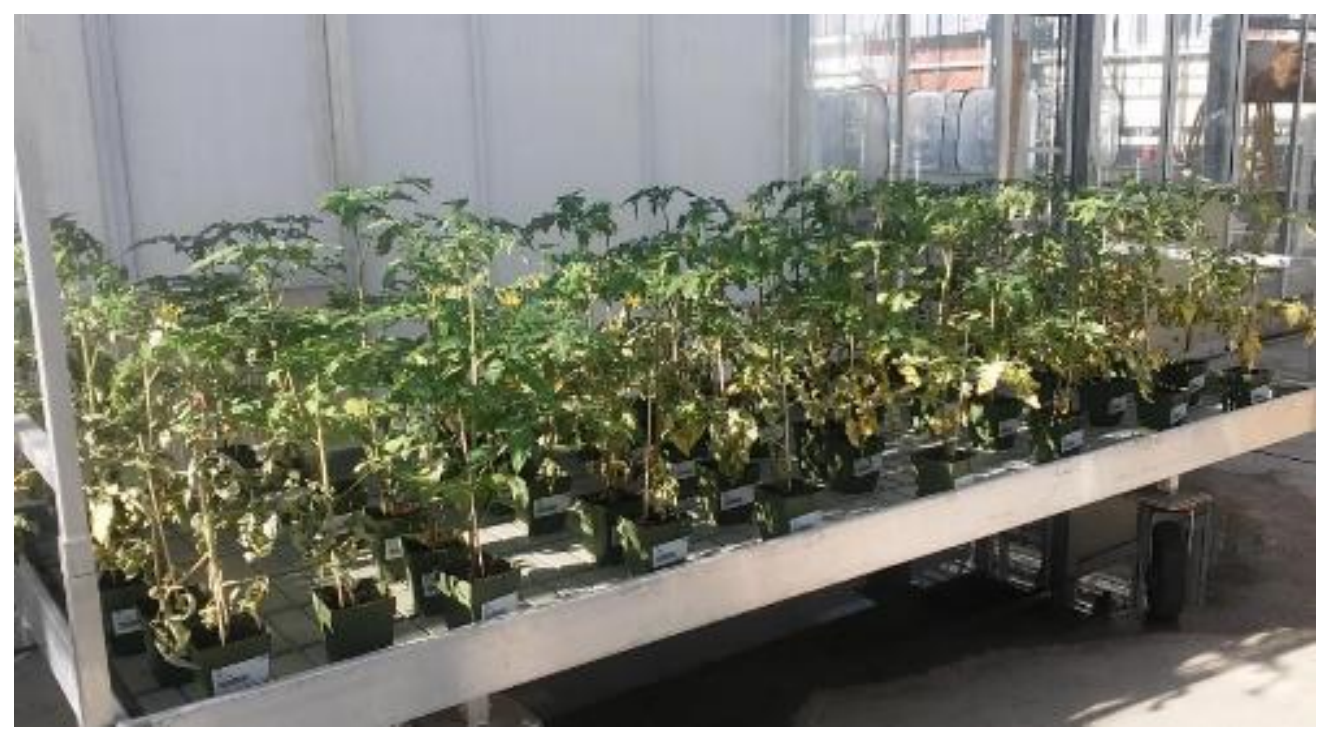

Figure 6.1 experimental set up explorative study late blight with tomato plants.

Further field experiments with potatoes are recommended, but to achieve the same result as with the fungicide, spraying with alternative products should be complemented with other measures. 


\section{9 field experiment potatoes}

In 2019 a field experiment was set up with potatoes. This research is reported in an anonymised report (Evenhuis and Schepers 2020). In the paragraphs below a summary of this research is given.

The cultivated potato plants (cv. Agria) were grown at Wageningen University and Research location Lelystad. The experiment was treated conform local good agricultural practice. A plot consisted of 3 meters (4 rows) of 11 meters. The trial was carried out in four replications. Different alternative foliar sprays were compared to the reference (no treatment). A no treatment, BCD spraying of humic acid product, EFGH testing of different products.

Disease observations were carried out once a week. The number of infected leaves was counted, and percentage infected foliage was calculated or percentage necrotic foliage per plot was estimated. The Standard Area under Disease Progress Curve (StAUDPC) was calculated (indication for disease development during the growing season).

The crop was harvested. Tubers were sorted out, weighed and counted, before storage. After storage rotten tubers were sorted out weighed and counted. The rest of the potatoes were weighed and counted.

Table 1. Objects Humic acid product

\begin{tabular}{|l|l|l|}
\hline Object & Description & \\
\hline A & Reference untreated & \\
\hline B & $\begin{array}{l}\text { Humic acid product } \\
\text { Soil application: }\end{array}$ & $100 \mathrm{~L} /$ ha before sowing \\
\hline C & $\begin{array}{l}\text { Humic acid product } \\
\text { Foliar spraying: }\end{array}$ & $\begin{array}{l}\text { Foliar } 1,5 \mathrm{~L} / \text { ha just before bulbing and two weeks later second } \\
\text { treatment }\end{array}$ \\
\hline D & $\begin{array}{l}\text { Humic acid product } \\
\text { Foliar spraying: }\end{array}$ & $\begin{array}{l}\text { Foliar 3 L/ha just before bulbing and two weeks later second } \\
\text { treatment }\end{array}$ \\
\hline
\end{tabular}

Due to the dry and hot weather in June and July 2019 the late blight epidemic developed moderately. By the end of August the untreated reference reached a disease severity level of almost $100 \%$ and disease assessments were stopped. In figure 6.1 the effect of the different treatments can be seen for late blight development.

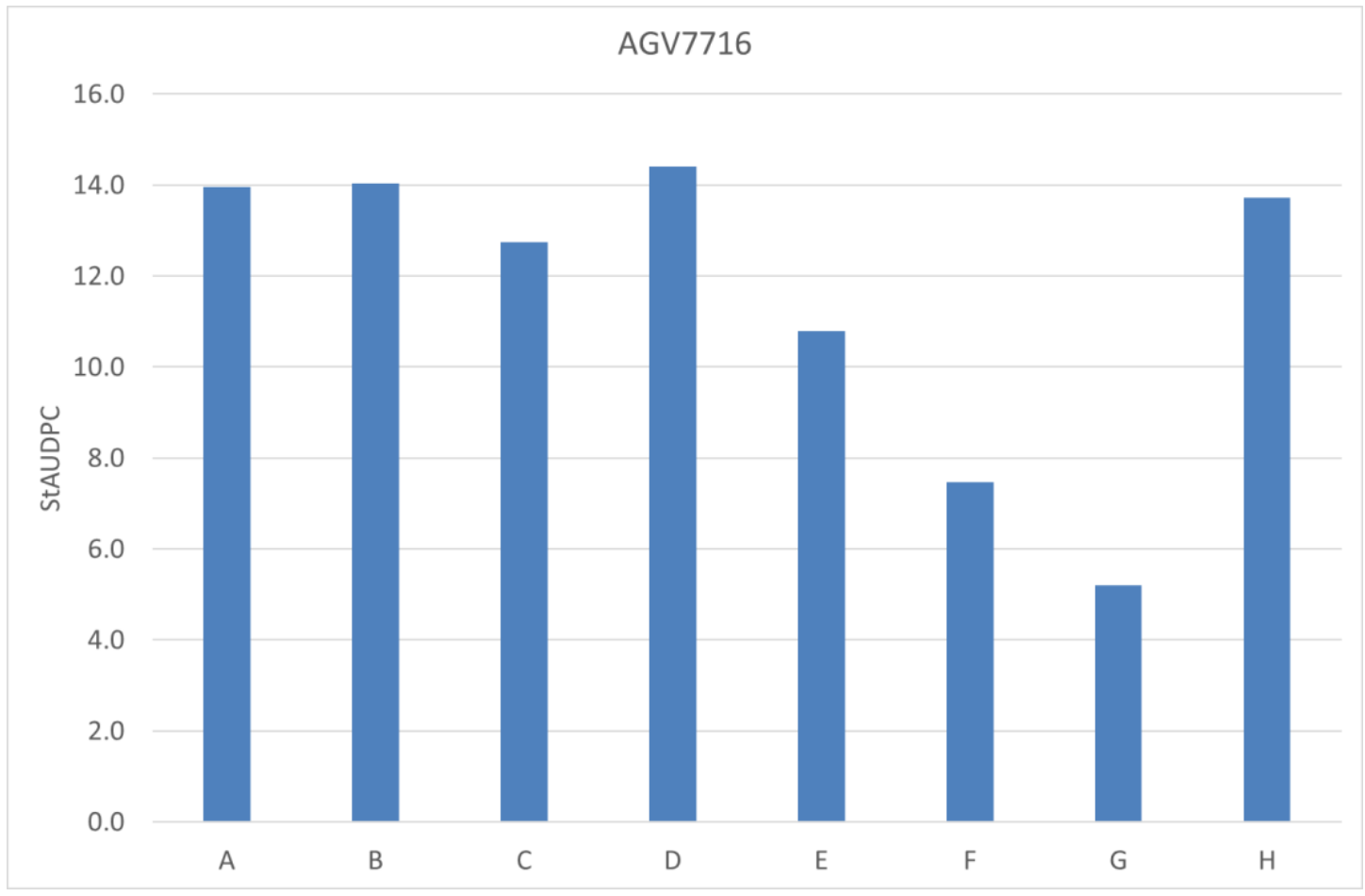

Figure 6.1 Potato late blight StAUDPC as a result of various spray schedules 
Tuber blight incidence was low and based on weighed none of the treatments were significantly different from the untreated control. Weather conditions were not conducive for tuber blight since rain was limited and foliar blight severity remained low until half August.

Total yield was around $40 \mathrm{t} / \mathrm{ha}$ which was medium yield considering the dry season. Due to foliar blight severity increasing strong in the second half of August desiccation was carried out early September. Normally in September the crop could grow and a yield of around 60 t/ha would have been possible.

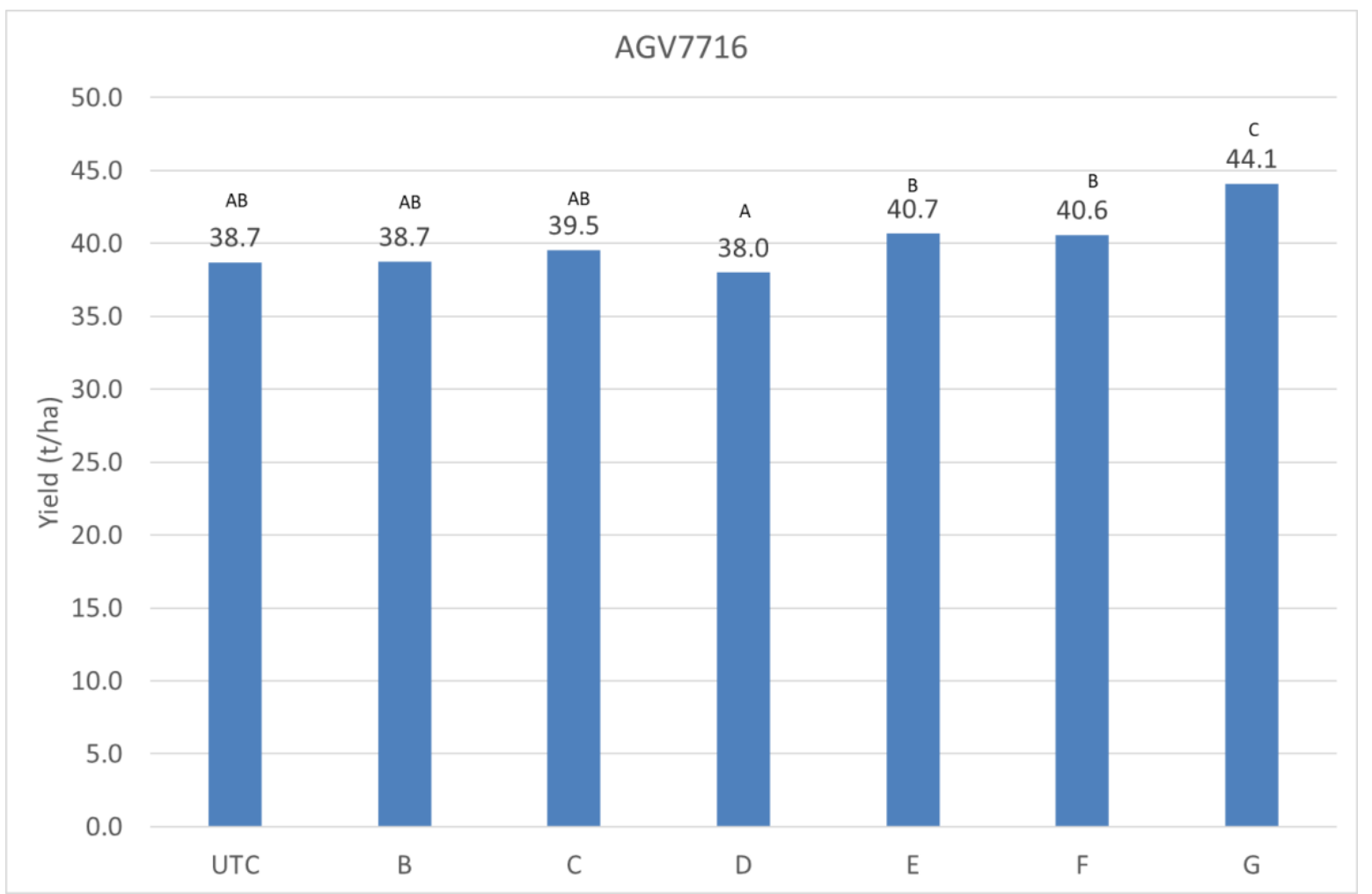

Figure 6.2 Yield ( $t / h a)$ as a result of the various spray treatments. Values above columns followed by the same character are not significantly different $(P=0.05)$.

\section{Conclusion}

No phytotoxicity was observed, the biological crop protection products used were crop safe. Based on the StAUDPC treatments B, C, D (Humic acid treatments) and E, F showed no efficacy to control potato late blight, disease severity was comparable to the untreated control. Treatment $\mathrm{G}$ did show a suppressing effect on the development of potato late blight. 


\section{$7 \quad$ Conclusions and recommendations}

Based on the literature research the interviews of experts and the experiments, it can be concluded that:

- There are several mechanisms of humic acids described that might stimulate plant growth. Depending on the situation the effect of humic acids can be high or low. On average, yield increases can be expected. In the Netherlands optimal growing conditions might be the reason that positive effects of humic acids on plant growth under field conditions are not observed. The field experiments described in this report confirm this.

- Humic acids of Ecoson is intended as a plant biostimulant, not a food/feed additive because of the animal manure status.

- Humic acids of Ecoson can be sprayed with normal field sprayers in doses 120 I Humic acids of Ecoson/hectare. Crop spraying with doses 1,5-3 I Humic acids of Ecoson/hectare per spraying (two times spraying) seemed safe for onion, potatoes and tomato plants.

- In experimental setups application rates are within the range 1.5 to $20 \mathrm{~kg}$ humic substances/ha. Optimal application rates depend on humic substances product and crop. Application rates of circa $8 \mathrm{~kg}$ humic substances/ha are thought to be an adequate guideline.

- A lot of research about Humic acids is done but little information is found on the use of humic acids under field situations in the Netherlands.

- Humic acids are used for fruit trees for stimulating root growth and for their chelating properties. This might be an interesting market for humic acids.

- Cultivations under sub optimal conditions might be markets for humic acids (for instance organic farmers)

Marketing of humic acids requires further proof of product. Field experiments are needed followed by word-of-mouth advertising. Not only the farmers should be persuaded but also the advisors or fertilizer suppliers. 


\section{References}

Atiyeh R.M., S. Lee, C.A. Edwards, N.Q. Arancon, J.D. Metzger, 18 January 2002, The influence of humic acids derived from earthworm-processed organic wastes on plant growth, Bioresource Technology 84 (2002) 7-14

Calvo P., L. Nelson, J. W. Kloepper, 8 May 2014, Agricultural uses of plant biostimulants, Plant Soil (2014) 383:3-41

Dobbs L.B., Canellas L.P., Olivares F.L., Aguiar N.A., Pereires Peres L.E., Azevedo M, Spaccini R, Piccollo A, Facanha A.R., 25 februari 2010, Bioactivity of Chemically Transformed Humic Matter from Vermicompost on Plant Root Growth, J. Agric. Food Chem., Vol. 58, No. 6, 2010 Escghi et al. (2015)

Evenhuis A. \& H.T.A.M. Schepers, 2020. Efficacy to control potato late blight by applying biological crop protection products Wageningen Research, WPR report 868

El-Hassanin A.S., M.R. Samak, Moustafa, N. Shafika, A.M. Khalifa M. Ibrahim Inas, 10 November 2016, Effect of Foliar Application with Humic Acid Substances under Nitrogen Fertilization Levels on Quality and Yields of Sugar Beet Plant, Int.J.Curr.Microbiol.App.Sci (2016) 5(11): 668-680

Hasset D. J., M. S. Bisesi, R. Hartenstein, 20 August 1986, Bacterial Action of Humic Acids, Soil Biology biochemistry Vol. 19. No. I, pp. 111-113, 1987

Ibrahim E.A., W.A. Ramadam, 16 January 2015, Effect of zinc foliar spray alone and combined with humic acid or/andchitosan on growth, nutrient elements content and yield of dry bean(Phaseolus vulgaris L.) plants sown at different dates, Scientia Horticulturae 184 (2015) 101-105

Du Jardin P., 29 October 2015 , Plant biostimulants: Definition, concept, main categories and regulation, Scientia Horticulturae 196 (2015) 3-14

Geel, W. van, B. Evenhuis en C. Topper, 2020b. Effect humuszurenproduct en zeewierextract bij zaaiuien. Verslag van een veldproef in 2019 te Lelystad. Wageningen Research, 32 pag, WPR report 870

Geel, W. van, B. Evenhuis en C. Topper, 2020a. Effect humuszuurproduct en zeewierextract bij uien. Verslag van een veldproef in 2018 te Lelystad. Wageningen Research, 34 pag, WPR report 869

Lehmann J. and Kleber M., 2015, The contentious nature of soil organic Matter, doi: $10.1038 /$ nature 16069

Mikkelsen L.R., 2005, Humic Materials for Agriculture, Better Crops/Vol. 89 (2005, No. 3)

Neri D., E. M. Lodolini, G. Savini, P. Sabbatini, G. Bonanomi, F. Zucconi, 2002, Foliar Application of Humic Acids on Strawberry (cv Onda) Proc. IS on Foliar Nutrition Eds. M.Tagliavini et al., Acta Hort. 594, ISHS 2002

Piccolo A., G. Pietrarnellara, J.S.C. Mbagwu, 1996, Effects of coal derived humic substances on water retention and structural stability of Mediterranean soils, Soil Use and Managment (1996) $12,209-213$

Rose M.T., Patti A. F., Little K.R., Alicia, Brown A.L., Jackson W.R., Cavagnaro T.R., 2014 A MetaAnalysis and Review of Plant-Growth Response to Humic Substances: Practical Implications for Agriculture, Advances in Agronomy, Volume 124, 2014 Elsevier Inc. ISSN 0065-2113

Sangeetha M., P. Singaram, March 2007, The effects of lignite humic acid and inorganic fertilizer additions on the productivity of typic haplustalf in Tamil Nadu, India, The Asian Journal of Soil Science (2007) 2 (1): 86-89

Selim E.M.2, A.A. Mosa, 23 januari 2012, Fertigation of humic substances improves yield and quality of broccoli and nutrient retention in a sandy soil, J. Plant Nutr. Soil Sci. 2012, 175, 273-281

Selim E.M., Shedeed S.I., Asaad F.F., El-Neklawy A.S., 2012, Interactive Effects of Humic Acid And Water Stress on Chlorophyll and Mineral Nutrient Contents of Potato Plants, Journal of Applied Sciences Research, 8(1): 531-537, 2012 
Sharif M., Khattak R.A., Sarir M. S., 19 Aug 2006, EFFECT OF DIFFERENT LEVELS OF LIGNITIC COAL DERIVED HUMIC ACID ON GROWTH OF MAIZE PLANTS, Communications in Soil Science and Plant Analysis, 33:19-20, 3567-3580, DOI: 10.1081/ CSS-120015906 Siddiqui et al. 2009

Sjoerdsma P., A. Laarman, R. Thijssen, B. Bolt, 7 juni 2013 Waarde uit water: de terugwinning van humuszuren uit de reststroom van de ontkleuring van drinkwater $\mathrm{H} 2 \mathrm{O}$-Online /

Spijker J., R.J.N. Comans, J.J. Dijkstra, B.J. Groenenberg, A.J. Verschoor, Uitloging van grond een modelmatig verkenning, RIVM Rapport 711701077/2009

G. Verlinden , B. Pycke, J. Mertens , F. Debersaques , K. Verheyen , G. Baert , J. Bries \& G. Haesaert (2009) Application of Humic Substances Results in Consistent Increases in Crop Yield and Nutrient Uptake, Journal of Plant Nutrition, 32:9, 1407-1426, DOI: $10.1080 / 01904160903092630$

Van Zomeren A., Comans R.N.J., 2007, Measurement of Humic and Fulvic Acid Concentrations and Dissolution Properties by a Rapid Batch Procedure, VOL. 41, NO. 19, 2007 / ENVIRONMENTAL SCIENCE \& TECHNOLOG 


\section{Appendix 1 Scheme for extraction of humic acids}

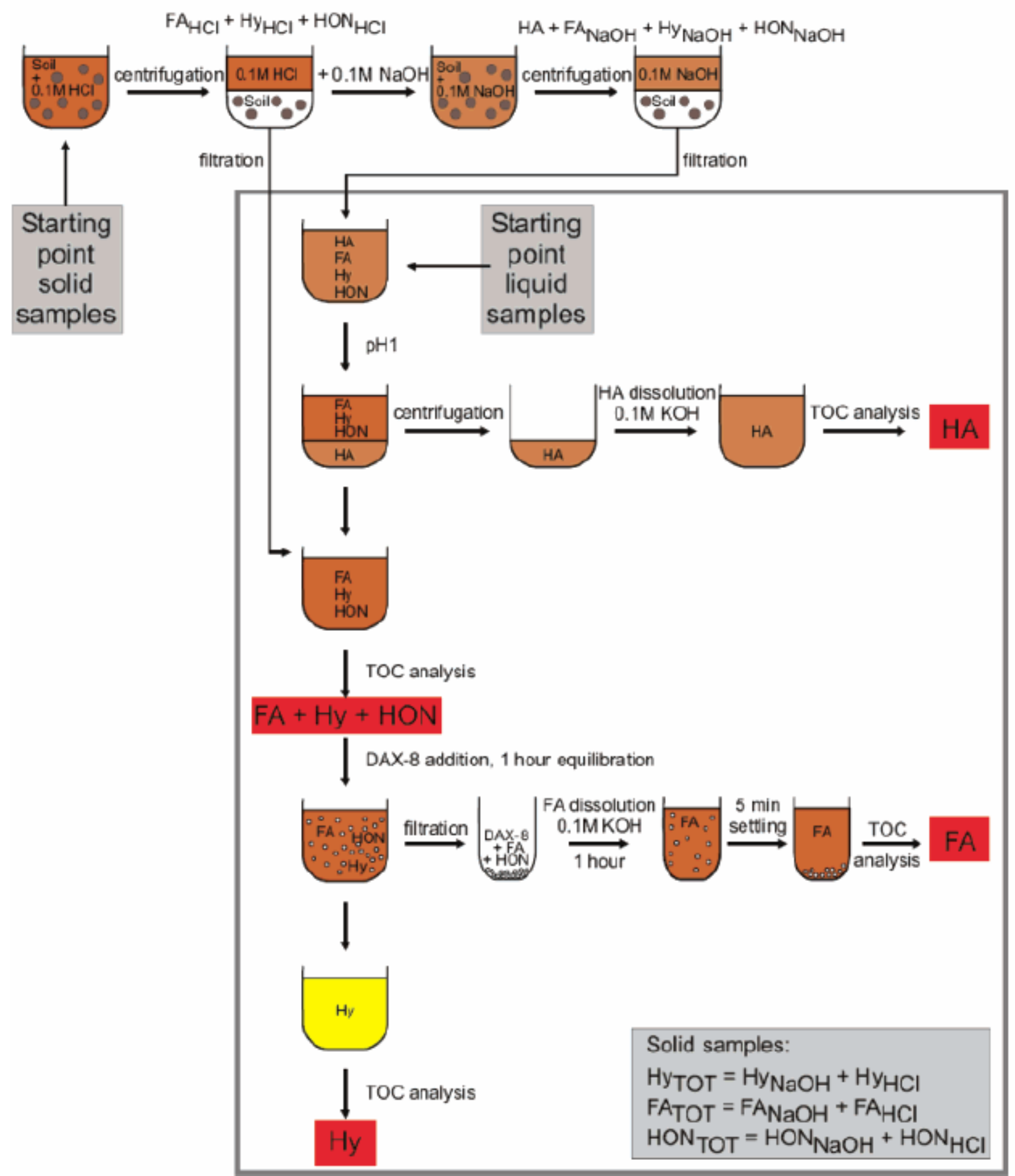




\section{Appendix 2 Table A2.1 Summary of research on humic acid products. Source: Calvo et al. (2014)}

Tahk 1 Summary of reported effects of humic substances on plant growth, mutrient uptake, and plant physiology

\begin{tabular}{|c|c|c|c|c|c|}
\hline Crop & Type of Humic Subtunce & Reference & Stuaty Conditions & $\begin{array}{l}\text { Reported Effects on Growth and } \\
\text { Nutriant Upalake }\end{array}$ & Effects on Plunt Physiology \\
\hline Cuaniber (Cxacumis sativis) & Humic acid & Aguine of al 2009 & Growth chamber & No cflies on root grouth & 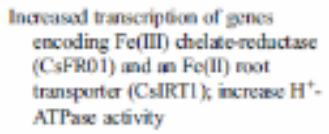 \\
\hline Cucumber & Humic acid & FL-Nemr of al 2012 & $\begin{array}{l}\text { Field tests in tuo ycars with foliar } \\
\text { sprays }\end{array}$ & $\begin{array}{l}\text { Increasad plent growth and yidd; } \\
\text { enhanoed uptike of } \mathrm{N}, \mathrm{P}, \mathrm{K}, \mathrm{Ca} \\
\text { and } \mathrm{Mg}\end{array}$ & \\
\hline Cucumber & Humic scid & Kankirt et al. 2009 & $\begin{array}{l}\text { Yield and fruit- quality stualy in } \\
\text { ground in organic production } \\
\text { groenbouse conducted in two years }\end{array}$ & $\begin{array}{l}\text { Inscrassed lotal fruit yidd, lotal soluble } \\
\text { sugsers reducing sugars, and } \\
\text { chlorophyll b }\end{array}$ & \\
\hline Cucamber & Humic acid & Moea ef al. 2010 & $\begin{array}{l}\text { Hydopoeic caltare in growth } \\
\text { chamber }\end{array}$ & $\begin{array}{l}\text { Increasal shook gouth; increased } \\
\mathrm{NO}_{3} \text { in shooks and decreasod } \mathrm{NO}_{3} \\
\text { in roes }\end{array}$ & $\begin{array}{l}\text { Increasod } \mathrm{H}^{+} \text {-ATPase adivity and } \\
\text { significant changes in roosto-shoot } \\
\text { distribation of } \mathrm{NO}_{3} \text {, cytakinins, } \\
\text { and polyamines. }\end{array}$ \\
\hline Cucumber & Fulvis acid & Rauthan and Schritar 1981 & Growth chamber hydroponis culture & $\begin{array}{l}\text { Increased shoot and rook dy weight, } \\
\text { numbers of flowers per plant, and } \\
\text { uptake of } \mathrm{N}, \mathrm{P}, \mathrm{K}, \mathrm{Ca}, \mathrm{Mg}, \mathrm{Cu}, \mathrm{Fe} \text {, } \\
\text { and } \mathrm{Zn}\end{array}$ & \\
\hline 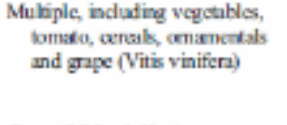 & Humic substance & Morard et al. 2011 & $\begin{array}{l}\text { Hydroponic culture and field trial } \\
\text { (grope) }\end{array}$ & $\begin{array}{l}\text { With seme of the aested planks, } \\
\text { incroased plant fresh weight, } \\
\text { number of flowar, and water use } \\
\text { efficiency. With gape, increased } \mathrm{N} \\
\text { content of must }\end{array}$ & \\
\hline Ginape (Vitis vinifena) & Humic substance & Sinchez-Sinchezet al, 2006 & $\begin{array}{l}\text { Field trials ovar two years testing } \\
\text { combination of Fe chelates with } \\
\text { humic subotances }\end{array}$ & $\begin{array}{l}\text { Increased uptake of } \mathrm{P} \text { and } \mathrm{Fe} \text {, } \\
\text { doercased uptake of } \mathrm{Na}\end{array}$ & \\
\hline $\begin{array}{l}\text { Micro-Toen tomato (Solanam } \\
\text { byopersicam) }\end{array}$ & Humic suhstances & Cancllss ot al. 2011 & Germination paper in growth chamber & Enhanoed number of lixcral noots & $\begin{array}{l}\text { Auxi-like activity detected by } \\
\text { attivasice of the auxin synthetic } \\
\text { rcporter DR5: GUS }\end{array}$ \\
\hline $\begin{array}{l}\text { Anabidepsis thalina, fommo, } \\
\text { maixe (Zea mays) }\end{array}$ & Humic suhstances & Dobhss of al. 2010 & Growth chamber & Increased hateral mos emargance & $\begin{array}{l}\text { Increased } \mathrm{H}^{+}-A T \text { Pare activity in mot } \\
\text { vesides, setivatal auxin synthetic } \\
\text { reporter DR5: GUS }\end{array}$ \\
\hline $\begin{array}{l}\text { Anabidopsis thalians, micxv-Tom } \\
\text { tomato }\end{array}$ & Fulvic acid & Dubbss of al. 2007 & $\begin{array}{l}\text { For Aràidopsis, miai-hyuroponic } \\
\text { system in growth chambar. }\end{array}$ & $\begin{array}{l}\text { Increasual bateral rook grvath in } \\
\text { Arabidopois and wild type micro- } \\
\text { Tom tomato. }\end{array}$ & $\begin{array}{l}\text { No peumobice of biteral root } \\
\text { emangence with dgt tomso muxant } \\
\text { insensitive to LAS }\end{array}$ \\
\hline Taenato & Humic seidls & Adani et at $199 \mathrm{~g}$ & Hychoponic cultare & $\begin{array}{l}\text { Increased growth of noots and shouts } \\
\text { enhanoed ugeske of } \mathrm{N}, \mathrm{P}, \mathrm{Fc} \text {, and } \\
\mathrm{Cu}\end{array}$ & \\
\hline Toenato & Humic axid & Yildrin 2007 & $\begin{array}{l}\text { In-ground groenhous test for yield } \\
\text { cooducted during two growing } \\
\text { sessens }\end{array}$ & 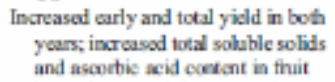 & \\
\hline \multirow[t]{2}{*}{ Toenabo } & Fulvic acid and hamic acid & Lulakis and Petsas 1995 & $\begin{array}{l}\text { Growth chamber tests with seadlings } \\
\text { in Patri plates }\end{array}$ & $\begin{array}{l}\text { Enhanoed root and shoot grouth at } \\
14 \text { days after seoding }\end{array}$ & \\
\hline & Fulwic acid and hamic acid & Chenet al. 2004 & & & \\
\hline
\end{tabular}




\begin{tabular}{|c|c|c|c|c|c|}
\hline Crop & Type of Thunic Substance & Reficrance & Study Conditions. & $\begin{array}{l}\text { Reported Effects on Growth and } \\
\text { Nutrint Uptake }\end{array}$ & Effects on Mant Plysiology \\
\hline $\begin{array}{l}\text { Soybean (Glycine max), nalun } \\
\text { (Cuesumis melo), and rycgans } \\
\text { (Lolium perenne) }\end{array}$ & & & $\begin{array}{l}\text { Hydroposic cultare in growth } \\
\text { chambers with difling leveds of } \\
\text { Fe and } \mathrm{Zn}\end{array}$ & 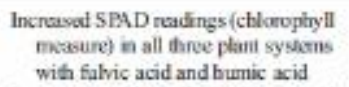 & \\
\hline Busd (Ocamum basilicum) & $\begin{array}{l}\text { Humic acid with and } \\
\text { whentout PCPR }\end{array}$ & Befiogiar et al 2013 & $\begin{array}{l}\text { Fidd lests with scoul tratments and } \\
\text { folar gangs }\end{array}$ & $\begin{array}{l}\text { Increased yickd of oil with bumic scid } \\
\text { aloos and in combinaben with } \\
\text { PCPR }\end{array}$ & \\
\hline Okna (Abdrnoschus esculentus) & Humic acids & Kim at al 2010 & In-ground test inside wire bouse & $\begin{array}{l}\text { Incrasod yield (fruits par plant) at } \\
\text { reoommended fartifity but not is } \\
50 \% \text { fiatility lavel }\end{array}$ & \\
\hline Pokato (Solanum tubavasm) & Hunic acid & Sclm at al. 2012 & $\begin{array}{l}\text { Fidd study with differen walcr } \\
\text { regimes, applicaion throught } \\
\text { fertigation system }\end{array}$ & 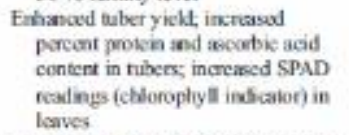 & \\
\hline Wheat (Triticum acstivum) & Humic axid & Tahir at al. 2011 & $\begin{array}{l}\text { Pot trial with calcaroous and non- } \\
\text { calcarcous field sonk with tree } \\
\text { levels of } N, P \text {, and } K\end{array}$ & $\begin{array}{l}\text { Increasod plant hcight and dry weight } \\
\text { of roots ind shoots; sthancod } \\
\text { upsake of } \mathrm{N}\end{array}$ & \\
\hline Wheat & Fulvic acid & Dunotone et al. 1988 & $\begin{array}{l}\text { Glashouse, grow th chamber, and } \\
\text { fidd trisls with foliar sprays of } \\
\text { fulvic acid }\end{array}$ & $\begin{array}{l}\text { Increased plant growith in some studies } \\
\text { but not in ofhers. No incresses in } \\
\text { yield or water ase in ficld tests }\end{array}$ & 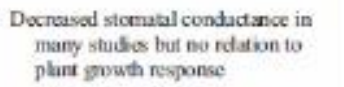 \\
\hline Wheat & Fulvic acid & Xudon 1986 & $\begin{array}{l}\text { Pot and field experiments with foliar } \\
\text { spays of fulvic axid }\end{array}$ & $\begin{array}{l}\text { Frhanced chlorophyll coesent; } \\
\text { incrased roots upeake of }{ }^{3} \mathrm{P} \text {; } \\
\text { partial alleviaticn of grain yichl } \\
\text { depression by moderate droaght }\end{array}$ & Docreasod stomatal condactance \\
\hline Whest & Fulvic acid & Peng at al $200 \mathrm{I}$ & $\begin{array}{l}\text { Hydroponics with varying levels of Se } \\
\text { as solium selenite }\end{array}$ & $\begin{array}{l}\text { Enhanced soedling root growth with } \\
\text { low levels of Se, reaboed } \\
\text { sympotoms of Se tovicity with high } \\
\text { levels of Se }\end{array}$ & $\begin{array}{l}\text { Redustion in Se-indeced oell } \\
\text { memberane pumealidity and froe- } \\
\text { pooline content with fitvic acid }\end{array}$ \\
\hline Wheat & Fulvic acid & Gu et al. 2001 & $\begin{array}{l}\text { Hydroposics with } 8 \text { conoxurations of } \\
3 \text { nare carth elcments }\left(\mathrm{La}^{3+}, \mathrm{GD}^{3 *} \text {, }\right. \\
\left.\text { and } \mathrm{Y}^{34}\right)\end{array}$ & $\begin{array}{l}\text { Increasod biciccumulacion of } \mathrm{La}^{3+} \text {, } \\
\mathrm{GD}^{*} \text {, and } \mathrm{Y}^{3+} \text { in noots and shoots, } \\
\text { resulting in less buildup in soil }\end{array}$ & $\begin{array}{l}\text { Actimation of phutamic cosaloacetic } \\
\text { tranaminase (GOT) enzyme }\end{array}$ \\
\hline Maize (Zaa nays) & Humic acids & Jndo et al. 2012 & Lab assays in minimal liquid medimm & $\begin{array}{l}\text { Promotion of not growtle increased } \\
\text { nuenber of mibotic sites on nots }\end{array}$ & $\begin{array}{l}\text { Increased number of mibtic sites and } \\
\text { peotce pump activity in roots }\end{array}$ \\
\hline Maire & Humic substances & Schisiven a al. 2010 & Grovuth chamber tes in hyduponics & Not assessed & 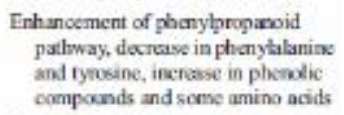 \\
\hline Maize & Humic acids & Cancllas et al, 2002 & Lab assays in minimal liquid medium & $\begin{array}{l}\text { Increased root dongation, } \\
\text { problifiratice of sevondary routs, } \\
\text { and woo sarface asa }\end{array}$ & 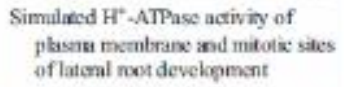 \\
\hline Maize & Fulvic acid & Anjum of al. $2011 \mathrm{~b}$ & $\begin{array}{l}\text { Pot riskts in net house under drooght } \\
\text { and no drought conditions }\end{array}$ & $\begin{array}{l}\text { Increasod leaf arca, plant dry wsight, } \\
\text { chlocophyll content, and yicld } \\
\text { under dought stress; increased } \\
\text { yield under non-drougle conditions }\end{array}$ & $\begin{array}{l}\text { Increased assimilation rate of } \mathrm{CO}_{2} \text { and } \\
\text { content of proline }\end{array}$ \\
\hline Maize & Fulvic and humic axids & Eyharaguibel at al. 2008 & & & \\
\hline
\end{tabular}




\begin{tabular}{|c|c|c|c|c|c|}
\hline Crop & Type of Hurnic Substance & Referance & Study Conditions & $\begin{array}{l}\text { Reportad Effects on Crowth and } \\
\text { Nutriant Uptake }\end{array}$ & Effects on Plant Physiology \\
\hline & & & $\begin{array}{l}\text { Application to 10-day old seadlings } \\
\text { with growth in liyduponic culluex } \\
\text { until cob filling stage }\end{array}$ & 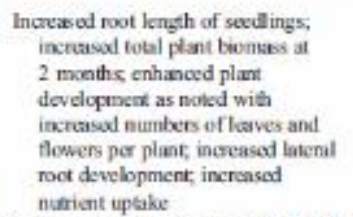 & \\
\hline Maize & Humic acids & Cindlis of al 2000 & Lab assays in minimad liquid matiam & Stimulatod root gowth ind moc longth & $\begin{array}{l}\text { Activated prosen pump actikation in } \\
\text { mot plasma memhnane vesicles }\end{array}$ \\
\hline Maize & Humic acids & Asli and Naummen 2010 & $\begin{array}{l}\text { Grouth chamber gudy in hydoponic } \\
\text { culnure and in soil with muliple } \\
\text { applications }\end{array}$ & $\begin{array}{l}\text { Inhikition of shoox but not noot growth } \\
\text { with high conoencrations of humic } \\
\text { acid, reduced trampiration }\end{array}$ & $\begin{array}{l}\text { Roduced hydraulic eonductivity } \\
\text { reduced water tran port from rook } \\
\text { medium to shoot }\end{array}$ \\
\hline Matee & Folvic acid and humic acid & Harper et al. 1995 & $\begin{array}{l}\text { Sealling gowth for foer days in } \\
\text { numiant solation with and withour } \\
\text { ahminum }\end{array}$ & $\begin{array}{l}\text { Enhanoed root dongation in absuce } \\
\text { of } \mathrm{Al} \text {, in presence of } \mathrm{Al} \text {, alleviat od } \\
\mathrm{Al} \text { toxiciry limitation of noct } \\
\text { clongation }\end{array}$ & \\
\hline Pexa (Pyrus communis) & Hunic acid & Marino of al. 2010 & $\begin{array}{l}\text { In vitro micropropagation curaditices } \\
\text { of shoct culneses }\end{array}$ & $\begin{array}{l}\text { Inprowed acclimstication and } \\
\text { micnogecopagation; increased } \\
\text { rooting, plink height, chlorophyll } \\
\text { content, and nutrient uptake }\end{array}$ & $\begin{array}{l}\text { Redaxed activiny of catalses and } \\
\text { malondialdehyde }\end{array}$ \\
\hline Peqper (Capsicum annuum) & Humic acid & Cinnin et at. 2010 & Grouth chamber in soil mix & $\begin{array}{l}\text { Increabed shoot and wook weights, alvo } \\
\text { incrased } \mathrm{N}, \mathrm{P}, \mathrm{K}, \mathrm{Ca}, \mathrm{Mg} \mathrm{S}, \mathrm{Mn} \\
\text { and } \mathrm{Cu} \text { under moderabe salk stross } \\
\text { conditions }\end{array}$ & 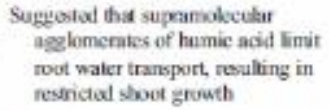 \\
\hline Pepper & Humic asids & Karakurt et al. 2009 & 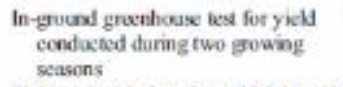 & 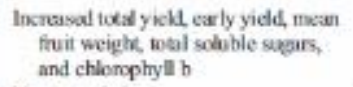 & \\
\hline Pepper & Fulvic acid & Aminifard atal 2012 & $\begin{array}{l}\text { Fiekd trial with chenches of fulvic axid } \\
\text { during wegetative gowh }\end{array}$ & Not recurded & $\begin{array}{l}\text { Increased fruik content of } \\
\text { eabohydrate, locil phenolics, } \\
\text { capsaicin, and curotenoids; } \\
\text { increased antioxidant activity in } \\
\text { frut. }\end{array}$ \\
\hline Lantana canara & Hamic acid and fulvic acid & Costa et al. 2008 & $\begin{array}{l}\text { Groenhouse tost in soilless mix for } \\
\text { propagation }\end{array}$ & $\begin{array}{l}\text { Increase bivmass of noos and shoos } \\
\text { erfice flowering of moted carting }\end{array}$ & $\begin{array}{l}\text { Upregulteion of AGAMOLS-1ke } \\
\text { gane (AGL) }\end{array}$ \\
\hline $\begin{array}{l}\text { Lemon troes (Citus fimon) on C. } \\
\text { macroph hila nootstock }\end{array}$ & Futvic acid & Sänchez-Sanchez d al. $20 \% 2$ & $\begin{array}{l}\text { Fidd wes in cechand with calcareoas } \\
\text { soil }\end{array}$ & $\begin{array}{l}\text { Increased foliar upeake of } \mathrm{Fe} \text { and } \mathrm{Cu} \\
\text { increasod yicld (fiunt wcight, fruit } \\
\text { equarorial di ameter, juice pli, and } \\
\text { viamin C }\end{array}$ & \\
\hline Wild olive (Olea europaen) & Fulvic acid & Musnillo ef all 2005 & $\begin{array}{l}\text { Field tests in scrils pollunted by trace } \\
\text { elements undar semi-arid } \\
\text { conditions }\end{array}$ & $\begin{array}{l}\text { Increased } \mathrm{N} \text { and chlorophyll content in } \\
\text { plants without increases to } \\
\text { plytotouic levels of } \mathrm{Cd}, \mathrm{Cu}, \mathrm{Pb}, \mathrm{TL} \\
\text { of } \mathrm{Zn}\end{array}$ & \\
\hline Greck fir (Abies cephalonica) & Fulvie acid & Zneavi et al. 2011 & $\begin{array}{l}\text { Study with embryonic odl lines to } \\
\text { evaluate the hormose-like effects }\end{array}$ & & $\begin{array}{l}\text { Fulvic acid inconched with the plaxe } \\
\text { bormonal sigraling pathway. }\end{array}$ \\
\hline
\end{tabular}




\begin{tabular}{|c|c|c|c|c|c|}
\hline Crop & Type of Humic Substance & Referance & Stuaty Conditions & $\begin{array}{l}\text { Reportod Effiects on Ginowth and } \\
\text { Nutrient Uptake }\end{array}$ & Effocts on Plant Physiology \\
\hline & & & $\begin{array}{l}\text { of fulvic axid on stages of sumatic } \\
\text { embryogenesis }\end{array}$ & $\begin{array}{l}\text { Increased prolifaration rate and } \\
\text { percentige of pro-embryonic } \\
\text { masses. }\end{array}$ & $\begin{array}{l}\text { incrased celluke ATP and } \\
\text { glusaoc-6-phoqphate. }\end{array}$ \\
\hline Beoch (Fugus syfvatica) & Fulvic acid & Asp and Burgyren 1990 & $\begin{array}{l}\text { Growth disenter and grouthouse tosts } \\
\text { with seatlings }\end{array}$ & $\begin{array}{l}\text { Fulvic acid-cumpletal Al was not } \\
\text { taken wp by roots roduced noot } \\
\text { uptake of } \lambda \mathrm{N} \text { and }{ }^{2} \text { P-phosphate. }\end{array}$ & \\
\hline Sunflower (Helianthas annuas) & Fulvic xid & Bocanogra of al. 2006 & $\begin{array}{l}\text { Growth chumber test with soedlings in } \\
\text { Hoaglund solution with } \mathrm{Fe} \\
\text { provided in dialysis tag }\end{array}$ & 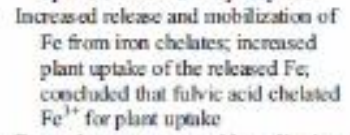 & \\
\hline Rice (Oryza saxiva) & Fulvic acid & Pandcya of al. 1998 & $\begin{array}{l}\text { Groweth chumber test with soedlings in } \\
\text { eslcanous soil with Fe-fulve seid, } \\
\mathrm{FeCl}_{3} \text { and }{ }^{5 t} \mathrm{Fe} \text { tracer }\end{array}$ & $\begin{array}{l}\text { Fe uptake wis graterwith application } \\
\text { of Fe-flulvic acid thas } \mathrm{FoCl}_{3}\end{array}$ & $\begin{array}{l}\text { Suggested thrs fulvic acid could } \\
\text { owerome the nac-imiting gepp of } \\
\text { trunsporting Fe from the soil } \\
\text { solution to plart roots by diffusion }\end{array}$ \\
\hline Rice & Hunic axid & Garcia et al 2012 & $\begin{array}{l}\text { Growth chamber best in natrieat } \\
\text { solutien and waser stress via } \\
\text { evaporation }\end{array}$ & $\begin{array}{l}\text { Increased plant growth and biceriass } \\
\text { useler wida defici conditions; } \\
\text { reduced exidhive stress of plants } \\
\text { under wata stress }\end{array}$ & 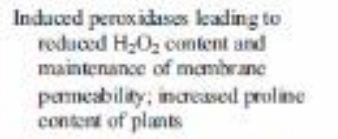 \\
\hline Rice & Humic acid & Garda ef al 2013 & $\begin{array}{l}\text { Growth chamber best in watrisnt } \\
\text { solution and waxer stress induced } \\
\text { by polyethylere glycol }\end{array}$ & 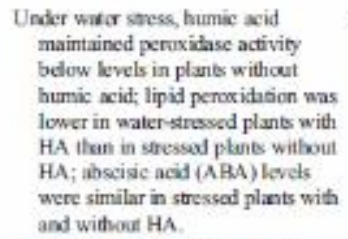 & 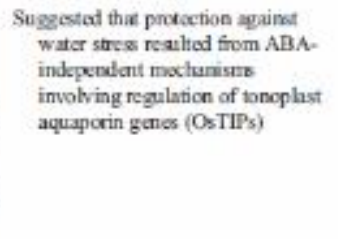 \\
\hline $\begin{array}{l}\text { Common bean (Phaseohus } \\
\text { vulyaris) }\end{array}$ & Fulvis acid & Poapst and Schnitzer 1971 & $\begin{array}{l}\text { Test with hypocoryl soctions of bean } \\
\text { seudlings }\end{array}$ & $\begin{array}{l}\text { Increased number of adventitious } \\
\text { roos with fulvic acid with and } \\
\text { withou IAA }\end{array}$ & \\
\hline Common Bcan & Humic acid & Aydin es al. 2012 & $\begin{array}{l}\text { Groenhouse test evaluating humie acid } \\
\text { for mitigation of salinity stress }\end{array}$ & 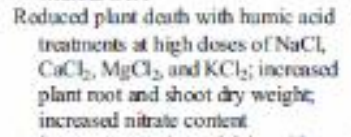 & $\begin{array}{l}\text { Under sulinity stress, humic acid } \\
\text { incrasusal prodine and electrolyte } \\
\text { leakags of plants }\end{array}$ \\
\hline Broed bean (Vicia fatos) & Fulve acid & Shathid a al 2012 & $\begin{array}{l}\text { Growth diamber wst in modified } \\
\text { Hoagland solution }\end{array}$ & 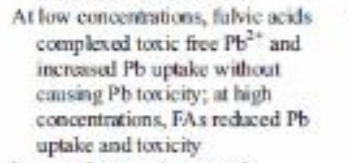 & $\begin{array}{l}\text { Po without fulvie asid inducod } \mathrm{H}_{2} \mathrm{O}_{2} \\
\text { and lipid peroxidetion; fulvic acid } \\
\text { dedsyod lipid peroxidation }\end{array}$ \\
\hline $\begin{array}{l}\text { Chrysanthemum } \\
\text { (Chrysantharram indisum) }\end{array}$ & Humic acid & Mazhur et al. 2012 & $\begin{array}{l}\text { In groend greenhouse test conducted } \\
\text { over two seasums with salinity } \\
\text { sthess }\end{array}$ & $\begin{array}{l}\text { lnacessod vegetative gromth; } \\
\text { flowering, total carbohydrates, } \mathrm{N} \text {, }\end{array}$ & \\
\hline
\end{tabular}

Table 1 (continued)

\begin{tabular}{|c|c|c|c|c|c|}
\hline Crop & Type of Humic Substance & Referance & Study Conditions & $\begin{array}{l}\text { Reportod Effects on Growth and } \\
\text { Nutrient Uptake }\end{array}$ & Effects œ Plant Physiology \\
\hline & & & & $\begin{array}{l}\text { P, and } K \text { with humic acid under } \\
\text { salinity stress }\end{array}$ & \\
\hline Pistachiv (Pistacia vera) & Hunic acid & $\begin{array}{l}\text { Moghadiam and Solcimani } \\
2012\end{array}$ & $\begin{array}{l}\text { Test of humic xid for mitigating } \\
\text { salinity stress }\end{array}$ & $\begin{array}{l}\text { Increased shoot growth with bumic } \\
\text { some acid treatments under salinity } \\
\text { stress }\end{array}$ & $\begin{array}{l}\text { Decreased levels of abscisic acid and } \\
\text { proline with some bumic acid } \\
\text { ifratments }\end{array}$ \\
\hline
\end{tabular}




\section{Appendix 3 Analytical report Koch Eurolab}

Verzend adres:

Wageningen Plant Research

Dhr.Th. Huiskamp

Postbus 430

8200 AK LELYSTAD

\section{LABORATORIUMANALYSES}

RAPPORTNUMMER: 191298702

Factuuradres:

Wageningen Plant Research

Postbus 430

8200 AK LELYSTAD 
Wageningen Plant Research

Dhr. Th. Huiskamp

Postbus 430

8200 AK LELYSTAD

ORGANISCHE MESTSTOF ANALYSE: HUMUSZUREN EN FULVINEZUREN

\begin{tabular}{|c|c|c|c|}
\hline Uw monsteraanduiding & & Labnummer & MONSTER DATUM \\
\hline 101 Humus Ecosun & & 98702 & $03-12-2019$ \\
\hline Parameters & Resultaat & Eenheid & \\
\hline Humuszuren & 10.5 & $\mathrm{~g} / \mathrm{kg}$ product & \\
\hline Fulvinezuren & 2.4 & $\mathrm{~g} / \mathrm{kg}$ product & \\
\hline
\end{tabular}

Toelichting:

Klassieke humuszuren analyse: schudverhouding 1 op 50 , extractant $0.25 \mathrm{M} \mathrm{KOH}$ eerste extract humuszuren + fulvinezuren, daarna afscheiding van fulfinezuren door toevoegen zoutzuur tot $\mathrm{pH} 2$. Daarna sprectrofotometrische analyse in vergelijking met een standaard met opgeloste humuszuren. 


\section{RAPPORT 191298702}

Wageningen Plant Research

Postbus 430

8200 AK LELYSTAD

\section{ORGANISCHE MESTSTOF ANALYSE OP BEMESTENDE WAARDE EN ZWARE METALEN}

\begin{tabular}{lll} 
Datum ontvangst & 3 -dec-2019 & Labnr. 98702 \\
Rapportagedatum & 8 -jan-2020 \\
Partij-aanduiding & 101 Humus Ecosun (soort monster) \\
Producent & Wageningen Plant Research \\
\hline PARAMETER & ANALYSE \\
& RESULTAAT
\end{tabular}

BEMESTENDE WAARDE IN kg per TON PRODUCT (= gram per KILO)

$\begin{array}{lc}\text { Droge stof } & 122 \\ \text { Vocht } & 878 \\ \text { Organische stof } & 70.4 \\ \text { Ruw as } & 52 \\ \text { pH } & 8.36 \\ \text { Totaal stikstof (N) } & 12.4 \\ \text { Fosfaat (gerekend als } \mathrm{P}_{2} \mathrm{O}_{5} \text { ) } & 2.0 \\ \text { Kali (gerekend als } \mathrm{K}_{2} \mathrm{O} \text { ) } & 9.4 \\ \text { Calcium (gerekend als } \mathrm{CaO} \text { ) } & 0.4 \\ \text { Magnesium (gerekend als } \mathrm{MgO} \text { ) } & 0.03 \\ \text { Natrium (gerekend als } \mathrm{Na}_{2} \mathrm{O} \text { ) } & 3.4 \\ \text { Nitraat (gerekend als } \mathrm{N} \text { ) } & <0.01 \\ \text { Ammonium (gerekend als } \mathrm{N} \text { ) } & 0.04 \\ \text { Zwavel totaal (gerekend als S) } & 4.2\end{array}$

\begin{tabular}{lccc}
\hline & & norm compost ${ }^{*}$ ) & $\begin{array}{r}\text { beoordeling } \\
\text { voldoet }\end{array}$ \\
Organische stof (gew \% in de droge stof) & 57.7 & $>10$ & voldoet \\
ZWARE METALEN IN mg PER kg DROGESTOF & & 51 & voldoet \\
Cadmium (Cd) & 1.0 & $\leq 50$ & te hoog \\
Chroom (Cr) & 16 & $\leq 60$ & voldoet \\
Koper (Cu) & 605 & $\leq 0.3$ & te hoog \\
Kwik (Hg) & 0.3 & $\leq 20$ & voldoet \\
Nikkel (Ni) & 110 & $\leq 100$ & te hoog \\
Lood (Pb) & 4 & $\leq 200$ & \\
Zink ( $\mathrm{Zn})$ & 1762 & &
\end{tabular}

Het monster voldoet niet aan de wettelijke eisen voor compost.

Met product wordt bedoeld het monster zoals ontvangen, ongedroogd. Dit rapport is bedoeld om een productieproces te beoordelen en advies, maar niet voor RVO doeleinden.

Dhr. C.F.M. Kodh (directesu)

Rapportnummer: 191298702

Layoutnr: 28 aug 2018 7ZBC XL7

Laboratorium chemisch en microbiologisch. Agrarischekringloopanalyses

Postbus 217400 AA DEVENTER (NL) Tel. 0570502010 Fax 0570652279 KvK. 38022558 E-mal intoecurolab.nl www.surolab.nl BTW/VAI/ID nr.: nl 8032.19.398.B.01 
RAPPORT: 191298702

Wageningen Plant Research

Dhr.Th. Huiskamp

Postbus 430

8200 AK LELYSTAD

ORGANISCHE MESTSTOF ANALYSE: HUMUSZUREN EN FULVINEZUREN

\begin{tabular}{lrr}
\hline Uw monsteraanduiding & Labnummer & MONSTER DATUM \\
102 Humus $x$ & 98703 & $03-12-2019$ \\
\hline
\end{tabular}

\begin{tabular}{lcl} 
Parameters & Resultaat & Eenheid \\
\hline Humuszuren & 6 & $\mathrm{~g} / \mathrm{kg}$ product \\
Fulvinezuren & 13.9 & $\mathrm{~g} / \mathrm{kg}$ product \\
& & \\
monstermateriaal & & \\
\hline
\end{tabular}

Toelichting:

Klassieke humuszuren analyse: schudverhouding 1 op 50 , extractant $0.25 \mathrm{M} \mathrm{KOH}$ eerste extract humuszuren + fulvinezuren, daarna afscheiding van fulfinezuren door toevoegen zoutzuur tot pH 2. Daama sprectrofotometrische analyse in vergelijking met een standaard met opgeloste humuszuren. 


\section{RAPPORT 191298702}

Wageningen Plant Research

Postbus 430

8200 AK LELYSTAD

ORGANISCHE MESTSTOF ANALYSE OP BEMESTENDE WAARDE EN ZWARE METALEN

\begin{tabular}{lll} 
Datum ontvangst & 3 -dec-2019 & Labnr. 98703 \\
Rapportagedatum & 8 -jan-2020 \\
Partij-aanduiding & 102 Humus x (soort monster) \\
Producent & Wageningen Plant Research \\
\hline PARAMETER & ANALYSE \\
& RESULTAAT
\end{tabular}

\begin{tabular}{|c|c|c|c|}
\hline Droge stof & 290 & & \\
\hline Vocht & 710 & & \\
\hline Organische stof & 137 & & \\
\hline Ruw as & 153 & & \\
\hline $\mathrm{pH}$ & 6.83 & & \\
\hline Totaal stikstof (N) & 1.4 & & \\
\hline Fosfaat (gerekend als $\mathrm{P}_{2} \mathrm{O}_{5}$ ) & 31.2 & & \\
\hline Kali (gerekend als $\mathrm{K}_{2} \mathrm{O}$ ) & 50.3 & & \\
\hline Calcium (gerekend als $\mathrm{CaO}$ ) & 0.7 & & \\
\hline Magnesium (gerekend als MgO) & 1.1 & & \\
\hline Natrium (gerekend als $\mathrm{Na}_{2} \mathrm{O}$ ) & 16.0 & & \\
\hline Nitraat (gerekend als N) & $<0.01$ & & \\
\hline Ammonium (gerekend als N) & 0.06 & & \\
\hline \multirow[t]{2}{*}{ Zwavel totaal (gerekend als S) } & 9.7 & & \\
\hline & & norm compost $\left.{ }^{*}\right)$ & beoordeling \\
\hline Organische stof (gew \% in de droge stof) & 47.2 & $>10$ & voldoet \\
\hline \multicolumn{4}{|l|}{ ZWARE METALEN IN mg PER kg DROGESTOF } \\
\hline Cadmium (cd) & 0.1 & $\leq 1$ & voldoet \\
\hline Chroom (Cr) & 2.2 & $\leq 50$ & voldoet \\
\hline Koper (Cu) & 6.9 & $\leq 60$ & voldoet \\
\hline Kwik (Hg) & 0.1 & $\leq 0.3$ & voldoet \\
\hline Nikkel (Ni) & 6.6 & $\leq 20$ & voldoet \\
\hline Lood (Pb) & 1.7 & $\leq 100$ & voldoet \\
\hline Zink (Zn) & 22 & $\leq 200$ & voldoet \\
\hline
\end{tabular}

Het monster voldoet aan de wettelijke eisen voor compost.

Met product wordt bedoeld het monster zoals ontvangen, ongedroogd. Dit rapport is bedoeld om een productieproces te beoordelen en advies, maar niet voor RVO doeleinden.

Dhr. C.F.M. Koch (directear)

Rapportnummer: 191298702

Layoutur:: 28 aug 2018728 CXLT 


\section{Appendix 4 Description of potato experiment}

\section{Material and methods}

In 2018, an experiment with potatoes and addition of humic acid product was conducted at a potato field of 1 hectare located between the Buntstraat and Koeveringsdijk in St. Oedenrode. Before the potatoes were planted, four alternate beds were treated with humic acid product and four beds were left untreated. All other treatments for cultivation (fertilisation, pesticides) were the same. The soil type was a sandy soil. The potato cultivar Hansa was used. The experiment started in May 2018 and ended in October 2018.

A dose of $120 \mathrm{~L}$ per hectare of the humic acid product of Ecoson was mixed with $80 \mathrm{~L}$ water, after which the product was applied to the soil. The location of the treated and non-treated beds was recorded with GPS.

The growth of tubers during the growing season was determined by PEKA KROEF with a protocol they use to determine yield per hectare.

\section{Results}

Application of the humic acid product to the field was easy and no problems like clogging appeared. The climate conditions were not in favour of the growth of potatoes, especially in cultivation on sandy soils, as there was too little water available. Therefore growth of tubers was slow and the farmer and PEKA KROEF decided that sampling before harvest was not needed. Visually, there was no difference between development of tubers with or without humic acid product treatment.

\section{Conclusions}

The research conducted was very basic.

It was concluded that:

- Humic acid product of Ecoson can be applied with normal agricultural machinery

In 2018, adding the humic acid product did not lead to differences in potato tuber growth, but this was only determined by a quick visual inspection. 


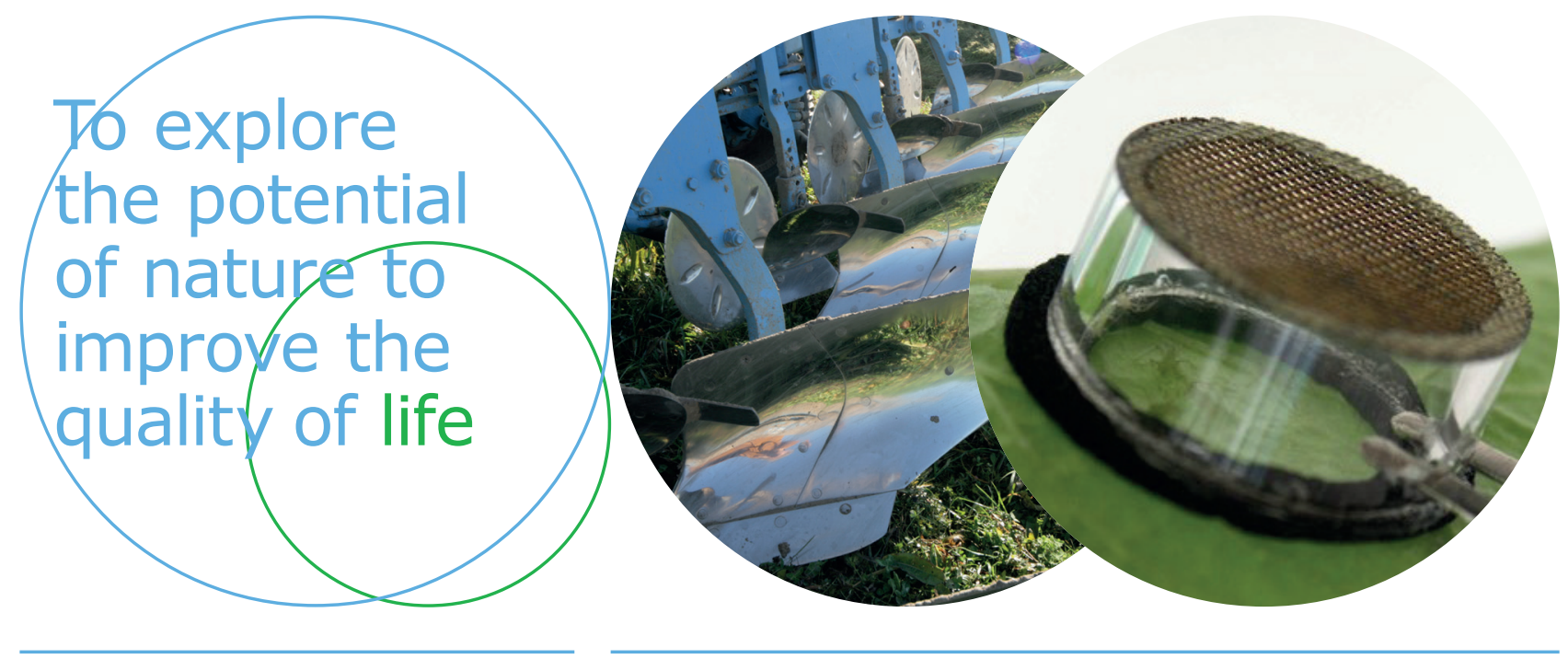

Wageningen University \& Research

\section{Open Teelten}

Edelhertweg 1

Postbus 430

8200 AK Lelystad

T (+31)3202911 11

www.wur.eu/fieldcrops

www.wur.nl/openteelten

Rapport WPR-867
The mission of Wageningen University \& Research is "To explore the potential of nature to improve the quality of life". Under the banner Wageningen University \& Research, Wageningen University and the specialised research institutes of the Wageningen Research Foundation have joined forces in contributing to finding solutions to important questions in the domain of healthy food and living environment. With its roughly 30 branches, 6,500 employees $(5,500 \mathrm{fte})$ and 12,500 students, Wageningen University \& Research is one of the leading organisations in its domain. The unique Wageningen approach lies in its integrated approach to issues and the collaboration between different disciplines. 